\title{
Applications of iodonium salts and iodonium ylides as precursors for nucleophilic fluorination in Positron Emission Tomography
}

\author{
Mekhman S. Yusubov, ${ }^{*, a, b}$ Dmitrii Yu. Svitich, ${ }^{\text {b }}$ Mariia S. Larkina, \\ and Viktor V. Zhdankin*,c \\ ${ }^{a}$ The Siberian State Medical University 634050 Tomsk, Russia \\ ${ }^{b}$ The Tomsk Polytechnic University, 634050 Tomsk, Russia \\ ${ }^{c}$ Department of Chemistry and Biochemistry, University of Minnesota Duluth, \\ Duluth, Minnesota, 55812, USA \\ E-mail:vzhdanki@d.umn.edu;yusubov@mail.ru
}

\begin{abstract}
This review summarizes the applications of iodonium compounds in the rapidly developing field of Positron Emission Tomography (PET). Reactions of diaryliodonium salts with fluoride anion have found wide practical application in PET as a fast and convenient method for the introduction of the radioactive $\left[{ }^{18} \mathrm{~F}\right]$-fluoride into radiotracer molecules. The best synthetic methods for the preparation of iodonium precursors for PET are described, the mechanistic aspects of nucleophilic fluorination reaction are discussed, and specific examples of the preparation of PET radioligands are provided.
\end{abstract}

Keywords: Iodonium salts, iodonium ylides, nucleophilic fluorination, PET, fluorine-18

\section{Table of Contents}

1. Introduction

2. Overview of PET and $\left[{ }^{18} \mathrm{~F}\right]$-Radiofluorination Methods

3. Iodonium Salts as Reagents for Nucleophilic Fluorination

3.1 Synthesis of diaryliodonium and aryl(heteroaryl)iodonium salts for PET

3.2 Mechanism of reactions of iodonium salts with fluoride anion

3.3 Selectivity of nucleophilic fluorination

3.4 Reactions of aryl(heteroaryl)iodonium salts with fluoride anion

3.5 Preparation of specific PET radioligands

4. Iodonium Ylides as Reagents for Nucleophilic Fluorination

4.1 Preparation and properties of iodonium ylides

4.2 Reactions of iodonium salts with fluoride anion 
5. Conclusions

6. Acknowledgements

References

\section{Introduction}

In recent years, compounds of polyvalent iodine ( $\lambda^{3}$ - and $\lambda^{5}$-iodanes) have emerged as versatile and environmentally benign reagents for various synthetically useful chemical transformations. ${ }^{1-}$ ${ }^{10}$ Aryliodonium salts represent an important class of $\lambda^{3}$-iodanes, particularly useful as reagents for arylation of various nucleophiles. ${ }^{11,12}$ Previously we have published a review in Arkivoc summarizing the preparation and synthetic applications of aryliodonium salts. ${ }^{12}$ The most important and synthetically useful reactions of diaryliodonium salts, $\mathrm{Ar}_{2} \mathrm{IX}$, include the following: the direct electrophilic arylations of various nucleophiles, the transition metal mediated cross-coupling reactions, and reactions involving the generation and trapping of the benzyne intermediates. Particularly important are the reactions of diaryliodonium salts with fluoride anion, allowing efficient introduction of fluorine into an aromatic ring via aromatic nucleophilic substitution. In recent years, nucleophilic fluorination reactions of diaryliodonium salts have found wide practical application in Positron Emission Tomography (PET) as a fast and convenient method for the introduction of the radioactive $\left[{ }^{18} \mathrm{~F}\right]$-fluoride into radiotracer molecules.

The purpose of the present review is to summarize the applications of iodonium compounds in the rapidly developing field of Positron Emission Tomography. In particular, the best synthetic methods for the preparation of iodonium precursors for PET will be overviewed, the mechanistic aspects of nucleophilic fluorination reactions will be discussed, and specific examples of the preparation of PET radioligands will be provided. The literature coverage is through May 2013.

\section{Overview of PET and Radiofluorination Methods}

Positron Emission Tomography is a powerful and rapidly developing area of molecular imaging that is used to study and visualize human physiology by the detection of positron-emitting radiopharmaceuticals labeled with the short-lived positron-emitting radionuclides ${ }^{11} \mathrm{C},{ }^{18} \mathrm{~F},{ }^{15} \mathrm{O}$, and ${ }^{13} \mathrm{~N}$. ${ }^{13-18}$ The principles of PET and its instrumentation have been previously summarized in several reviews. ${ }^{18-21}$ PET experiments provide direct information about metabolism, receptor/enzyme function, and biochemical mechanisms in living tissue. Unlike X-ray analysis, magnetic resonance imaging (MRI) or computerized tomography (CT), which mainly provide detailed anatomical images, PET can measure chemical changes that occur before macroscopic anatomical signs of a disease are observed. ${ }^{18}$ PET is emerging as a revolutionary method for 
measuring body function and tailoring disease treatment in living subjects, and it is widely applied both in clinical research ${ }^{22}$ and in drug development. ${ }^{14,23-26}$

Fluorine-18 is the most widely used radionuclide in PET because of its favorable physical and nuclear characteristics, such as, a short but manageable half-life $\left(t_{1 / 2}=109.7 \mathrm{~min}\right)$, which allows sufficient time for multistep synthetic labeling reactions, and a short positron linear range in tissue $(2.3 \mathrm{~mm})$ which gives the highest resolution PET images of all the available positron emitters. $^{18}$

Fluorine-18 is generally produced with a cyclotron, either as molecular fluorine gas or as $\left[{ }^{18} \mathrm{~F}\right]$-fluoride. Any application of fluorine-18 in PET demands rapid and efficient chemical transformation to introduce the fluorine-18 into the tracer of interest. $\left[{ }^{18} \mathrm{~F}\right]$-Fluoride anion is the preferred precursor because it can be produced in higher specific activity than molecular $\left[{ }^{18} \mathrm{~F}\right]-$ fluorine gas. There are two common pathways for the ${ }^{18} \mathrm{~F}$-labelling of an aromatic ring. Electrophilic ${ }^{18}$ F-fluorination leads only to carrier-added products because of the unavoidable addition of elemental fluorine to the target gas. The second pathway, via nucleophilic displacement of adequate leaving groups (e.g., $\mathrm{NO}_{2}$ or ${ }^{+} \mathrm{NMe}_{3}$ ), which are activated by electronwithdrawing substituents, by no-carrier-added (NCA) $\left[{ }^{18} \mathrm{~F}\right]$-fluoride, is generally used for the fluorination of electron-deficient arenes.

Nucleophilic ${ }^{18} \mathrm{~F}$-anion is produced with a cyclotron by the nuclear reaction from enriched $\left[{ }^{18} \mathrm{O}\right]$-water. ${ }^{18} \mathrm{~F}$-anion from the target is then trapped on an ion-exchange column, and the trapped ${ }^{18} \mathrm{~F}^{-}$is then eluted from the ion-exchange resin using potassium carbonate in a water/acetonitile solution. The obtained aqueous fluoride is a poor nucleophile because of its high degree of solvation. The addition of the phase-transfer reagent Kryptofix-222 ( $\mathrm{K}_{222}$; see structure $\mathbf{1}$ in Scheme 1), followed by the removal of water is usually required in order to improve the reactivity of the $\left[{ }^{18} \mathrm{~F}\right]$ fluoride ion for nucleophilic substitution reactions.

One of the most important radiotracers, 2- $\left[{ }^{18} \mathrm{~F}\right]$ fluoro-2-deoxy-D-glucose $\left(\left[{ }^{18} \mathrm{~F}\right] \mathrm{FDG}\right.$, structure 3), is commonly prepared by nucleophilic ${ }^{18} \mathrm{~F}$-substitution in which tetra- $O$-acetyl-2-Otrifluoromethanesulfonyl- $\beta$-D-mannopyranose $\mathbf{2}$ is treated with $\left[{ }^{18} \mathrm{~F}\right]$ fluoride ion (Scheme 1 ). ${ }^{27,28}$

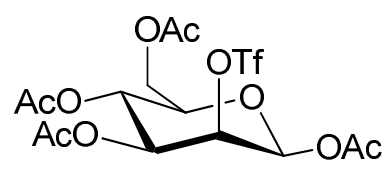

2
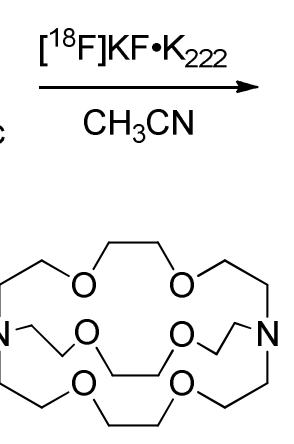

$1\left(\mathrm{~K}_{222}\right)$

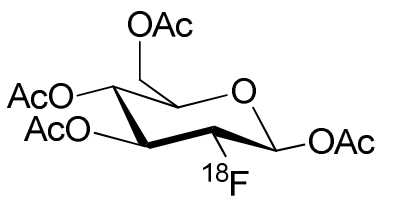

$\mathrm{HCl}$

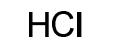

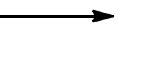

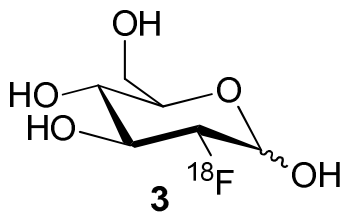

Scheme 1. Synthesis of 2-[ ${ }^{18}$ F]fluoro-2-deoxy-D-glucose 3 . 
$\left[{ }^{18}\right.$ F]FDG 3 is produced routinely by some 130 PET centers worldwide and is the most frequently applied radiotracer in PET. ${ }^{28,29}$ It has been shown to be a multi-purpose radiopharmaceutical with applications in a variety of diagnostic questions in neurology, oncology and cardiology. The production of $\left[{ }^{18} \mathrm{~F}\right] \mathrm{FDG}$ is now fully automated, and the synthesis of $\left[{ }^{18} \mathrm{~F}\right] \mathrm{FDG}$ can now be achieved in approximately 30 minutes with radiochemical yields greater than $70 \%{ }^{18}$

Although $\left[{ }^{18} \mathrm{~F}\right] \mathrm{FDG} 3$ is currently the most widely used ${ }^{18} \mathrm{~F}$-fluorinated radiotracer, ${ }^{29}$ the main focus of recent efforts in radiotracer synthesis has been the preparation of $\left[{ }^{18} \mathrm{~F}\right]$-fluorinated aromatic compounds. ${ }^{30-34}$ Direct nucleophilic substitution with ${ }^{18} \mathrm{~F}$-anion provides a convenient one-step pathway to a wide range of labeled aromatic compounds provided that the aromatic ring is suitably activated by an electron-withdrawing group (e.g. $\mathrm{CHO}, \mathrm{COMe}, \mathrm{COOMe}, \mathrm{NO}_{2}, \mathrm{CN}$, etc.) on the ortho or para positions to the leaving group. Common leaving groups used in nucleophilic ${ }^{18}$ F-fluorination reactions include nitro, trialkylamine, halogen, mesylate, tosylate, or triflate. ${ }^{18}$ Nitrobenzene derivatives are currently the most widely used precursors in the preparation of simple $\left[{ }^{18} \mathrm{~F}\right]$ fluoroaromatic compounds. However, the fluorination methods based on direct nucleophilic substitution in these aromatic precursors are not always suitable for the synthesis of the ${ }^{18} \mathrm{~F}$-labeled target compounds because of the harsh reaction conditions (high reaction temperatures and polar organic solvents). Moreover, these methods are reliant on the use of activated aryl groups, which limits the range of available $\left[{ }^{18} \mathrm{~F}\right]$ fluoroaromatic compounds to those rings which have electron-withdrawing substituents. The use of iodonium salts as precursors in nucleophilic ${ }^{18} \mathrm{~F}$-substitution reactions is an extremely useful alternative for the synthesis of a range of simple $\left[{ }^{18} \mathrm{~F}\right]$ fluoroaromatic compounds in good radiochemical yields and in short reaction times that would be otherwise unobtainable by traditional methods.

The first use of iodonium salts as a general route for the no-carrier-added (NCA) synthesis of unactivated $\left[{ }^{18} \mathrm{~F}\right]$ fluoroaromatic compounds with high specific activity was reported by Pike and Aigbirhio in $1995,{ }^{35}$ and since then the radiofluorination of diaryliodonium salts has attracted significant interest as valuable methodology for late stage introduction of fluorine into diverse aromatic substrates. The methodology introduced by Pike and Aigbirhio complements the other approaches based on nucleophilic aromatic substitution by providing a means to fluorinate electron-rich, as well as problematic electron-poor aromatic rings not easily accessed by direct substitution. ${ }^{35,36}$

\section{Iodonium Salts as Reagents for Nucleophilic Fluorination}

Currently, aryliodonium derivatives are becoming increasingly popular reagents in PET for the efficient introduction of $\left[{ }^{18} \mathrm{~F}\right]$-fluoride due to their exceptionally high reactivity in aromatic nucleophilic substitution reactions. Reactions of diaryliodonium salts with the cyclotronproduced $\left[{ }^{18} \mathrm{~F}\right]$-potassium fluoride in the presence of a phase-transfer reagent Kryptofix-222 provide a fast and convenient method of $\left[{ }^{18} \mathrm{~F}\right]$-fluorination as outlined in Scheme 2. The high 
reactivity of diaryliodonium salts $\mathrm{Ar}_{2} \mathrm{IX}$ in these reactions is explained by the "hyperleaving group ability" of the ArI group; for example, the leaving group ability of $\mathrm{PhI}$ is about million times greater than that of the triflate group. ${ }^{37}$

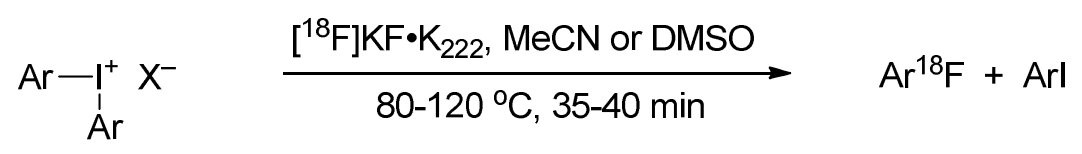

Scheme 2. General scheme of nucleophilic $\left[{ }^{18} \mathrm{~F}\right]$-fluorination with iodonium salts.

Diaryliodonium salts represent the most stable and well-investigated class of organoidodine(III) compounds. The first example of these compounds, (4iodophenyl)phenyliodonium bisulfate, was prepared by Hartmann and Meyer in 1894 from iodosylbenzene and sulfuric acid. ${ }^{38}$ Diaryliodonium salts $\mathrm{Ar}_{2} \mathrm{IX}$ are air- and moisture-stable compounds, the physical properties of which are strongly affected by the nature of the anionic part $\mathrm{X}^{-}$of the molecule. In particular, diaryliodonium salts with halide anions are generally sparingly soluble in many organic solvents, whereas triflate and tetrafluoroborate salts have a better solubility. The chemistry of aryl- and heteroaryliodonium salts has been extensively covered in several reviews. ${ }^{11,12,39}$

\subsection{Synthesis of diaryliodonium and aryl(heteroaryl)iodonium salts for PET}

A summary of synthetic approaches to iodonium salts has been provided in our previous review. ${ }^{12}$ General synthetic routes to diaryliodonium salts typically involve the initial oxidation of an aryl iodide to a $\lambda^{3}$-iodane, $\operatorname{ArIX}_{2}$, and then ligand exchange of $\mathrm{ArIX}_{2}$ with an arene or a nucleophilic arylating reagent (e.g., arylborates, arylstannanes, or arylsilanes) to obtain the diaryliodonium salt. In many cases a final anion exchange step is necessary. If an arene is used as a precursor, the presence of a strong acid is usually required to activate the hypervalent iodine reagent, $\operatorname{ArIX}_{2}{ }^{12,40}$ However, the precursors to PET ligands with functional substitution groups are usually not sufficiently stable under these reaction conditions. Therefore, a mild, reliable, and practical synthetic route is required for the preparation of iodonium salts that are used as PET precursors.

The most common modern methods of preparing iodonium PET precursors utilize a very mild reaction of arylstannanes or arylborates with [hydroxy(tosyloxy)iodo]arenes $\mathbf{4}$ according to Scheme $3 .^{41-44}$ [Hydroxy(tosyloxy)iodo] arenes $\mathbf{4}$ are prepared from the respective aryliodides 6 by oxidation to (diacetoxyiodo)arenes $\mathbf{5}$ followed by treatment with $p$-toluenesulfonic acid. Reactions of reagents 4 with arylstannanes exhibit excellent regioselectivity and give moderate to high yields (40-90\%) of iodonium tosylates 7. Reactions with arylboronic acids are regioselective for acids bearing an $o$-methyl substituent but not for arylboronic acids bearing an $o$-methoxy substituent, and the yields of products 7 are lower (20-50\%). Diaryliodonium tosylates 7 can be readily converted into corresponding halides $\mathbf{8}$ in moderate to high yields (27$88 \%$ ) by metathesis reactions. ${ }^{41}$ 


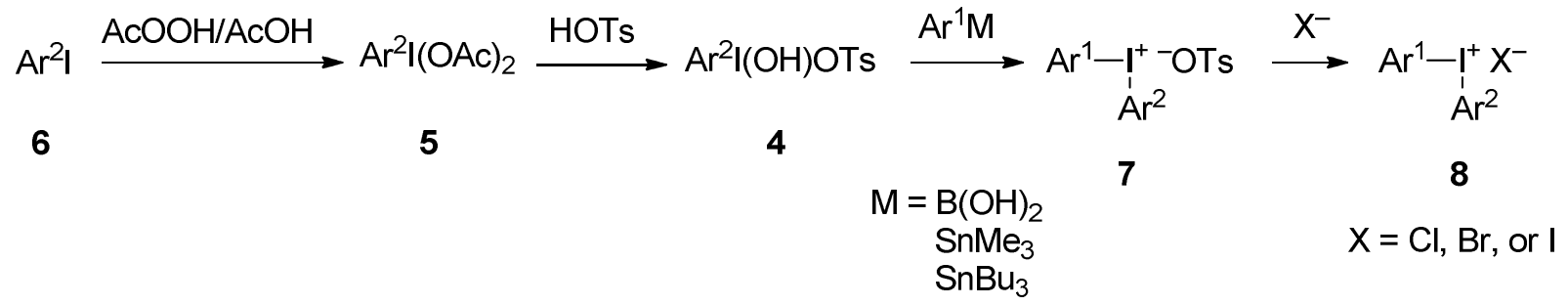

Scheme 3. General approach to the synthesis of diaryliodonium salts for PET.

An optimized, convenient procedure for the regioselective synthesis of functionalized diaryliodonium tosylates consists of the generation of a [hydroxy(tosyloxy)iodo]arene from a functionalized (diacetoxyiodo)arene and $\mathrm{TsOH} \bullet \mathrm{H}_{2} \mathrm{O}$ in situ followed by treatment with an electron-rich arene, such as anisole or thiophene, or with a functionalized arylstannane. This method provides expedient regiospecific access to a wide range of functionally diverse diaryliodonium tosylates in moderate to high yields (44-98\%). ${ }^{44}$

A specific example of the application of this approach to the preparation of iodonium precursors $\mathbf{1 0}$ in the synthesis of mGluR5 PET radioligands is shown in Scheme $4 .{ }^{45}$ The tributylstannylarenes 9 can be obtained in 39-57\% yield by treating the respective iodoarenes with $\mathrm{Sn}_{2} \mathrm{Bu}_{6}$ in the presence of catalytic $\mathrm{Pd}\left(\mathrm{PPh}_{3}\right)_{4}$ in toluene at $115{ }^{\circ} \mathrm{C}$. All prepared diaryliodonium salts $\mathbf{1 0}$ are stable for at least 12 months when stored at $4-5{ }^{\circ} \mathrm{C}$, in the dark and under $\operatorname{argon}^{45}$
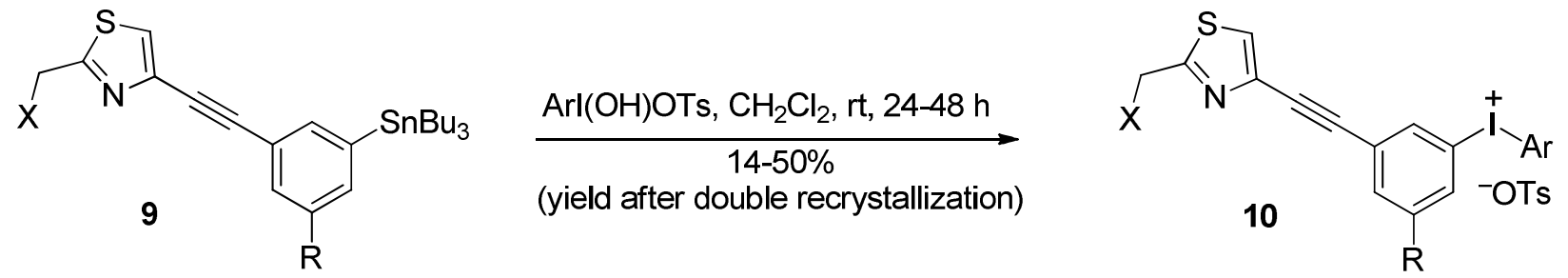

$\mathrm{X}=\mathrm{H}$ or $\mathrm{F}$

$\mathrm{R}=\mathrm{H}$ or $\mathrm{CN}$

$\mathrm{Ar}=\mathrm{Ph}$ or $4-\mathrm{MeOC}_{6} \mathrm{H}_{4}$

Scheme 4. Preparation of iodonium precursors in the synthesis of mGluR5 PET radioligands.

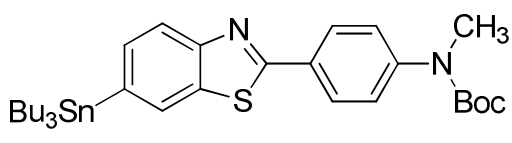

11

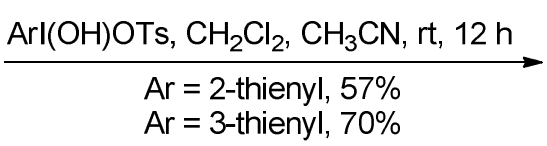

$\mathrm{Ar}=3$-thienyl, $70 \%$

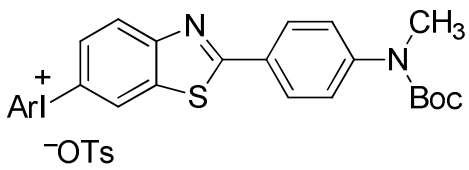

12

Scheme 5. Preparation of aryl(thienyl)iodonium salts for PET.

A similar procedure can be used for the synthesis of aryl(heteroaryl)iodonium salts. For example, aryl(thienyl)iodonium tosylates $\mathbf{1 2}$ have been prepared by treatment of 
tributylstannylarenes $\mathbf{1 1}$ with the respective [hydroxyl(tosyloxy)iodo]thiophenes (Scheme 5). ${ }^{46}$ Aryl(thienyl)iodonium tosylates $\mathbf{1 2}$ have been utilized as precursors in the synthesis of 2-aryl-6$\left[{ }^{18} \mathrm{~F}\right]$ fluorobenzothiazoles, which can be used as PET radioligands for $\beta$-amyloid plaques. ${ }^{46}$

The same synthetic route has been employed for the preparation of aryl- and thienyl-derived iodonium tosylates 13 (Scheme 6). ${ }^{47}$ Aromatic radiofluorination of the iodonium tosylate precursors 13 with $\left[{ }^{18} \mathrm{~F}\right]$ fluoride ions has been applied successfully to access $\left[{ }^{18} \mathrm{~F}\right]$ flumazenil, which is an important radiopharmaceutical product for the assessment of the central benzodiazepine receptor (cBZR) concentration in the brain. ${ }^{47}$<smiles>CCOC(=O)C1N=CN2c3ccc(C[Sb](C)(C)C)cc3C(=O)N(C)CC12</smiles>

$\mathrm{Ar}=$ 2-thienyl, 3-thienyl, $\mathrm{Ph}, 4-\mathrm{MeOC}_{6} \mathrm{H}_{4}, 3-\mathrm{MeOC}_{6} \mathrm{H}_{4}, 4-\mathrm{MeC}_{6} \mathrm{H}_{4}$

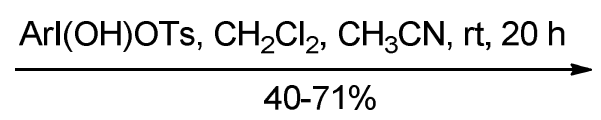

$40-71 \%$<smiles></smiles>

13

Scheme 6. Preparation of iodonium tosylate precursors to $\left[{ }^{18} \mathrm{~F}\right]$ flumazenil.

Phenyl(3-formylphenyl)iodonium PET precursors have been conveniently synthesized by the reaction of 3-formylphenylboronic acid with an organoiodine(III) intermediate generated in situ from iodobenzene and $m$-chloroperoxybenzoic acid (Scheme 7). ${ }^{48}$ The initially formed phenyl(3formylphenyl)iodonium triflate $\mathbf{1 4}$ can be further converted into the respective chloride or bromide salts 15 by treatment with aqueous $\mathrm{NaCl}$ or hydrobromic acid in methanol.

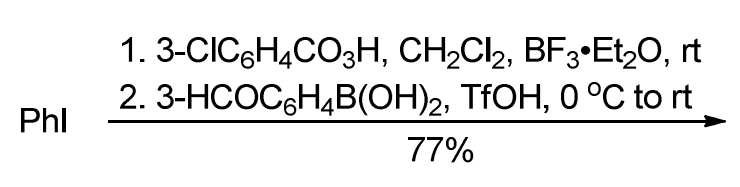

1. 3- $\mathrm{ClC}_{6} \mathrm{H}_{4} \mathrm{CO}_{3} \mathrm{H}, \mathrm{CH}_{2} \mathrm{Cl}_{2}, \mathrm{BF}_{3} \cdot \mathrm{Et}_{2} \mathrm{O}$, rt $77 \%$

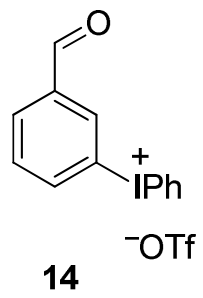

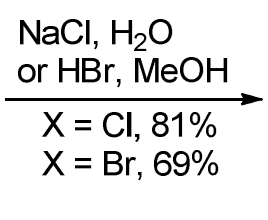

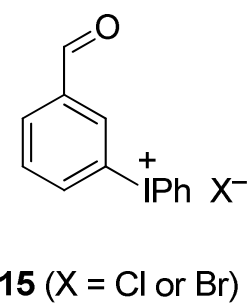

Scheme 7. Preparation of phenyl(3-formylphenyl)iodonium PET precursors.

A similar reaction of 3-(diacetoxyiodo)pyridine with arylboronic acids has been used for the preparation of several 3-pyridyl(aryl)iodonium salts, which are useful PET precursors to $\left[{ }^{18} \mathrm{~F}\right]$ fluoropyridine. ${ }^{31}$

\subsection{Mechanism of nucleophilic substitution reactions of iodonium salts}

Several general mechanistic studies on the reactions of diaryliodonium salts with nucleophiles have been published. Ochiai and co-workers performed a mechanistic study on the phenylation 
of $\beta$-keto ester enolates with diaryliodonium salts. The addition of an aryl radical trap to the reaction did not affect the outcome, which indicates that radical pathways are unlikely and the reaction occurs by direct coupling of the ligands on the hypervalent iodine center. ${ }^{49}$ It has been found that in the reaction of unsymmetric diaryliodonium salts $\mathbf{1 6}$ with nucleophiles, the most electron-deficient aryl group is transferred to the nucleophile with varying selectivities in agreement with the mechanism outlined in Scheme 8. The initial ligand exchange affords the hypervalent intermediates $\mathbf{1 7}$ and 18, in which with the electronegative ligand $\mathrm{Nu}$ occupies an axial position in agreement with general principles of hypervalent bonding. Fast pseudorotation occurs between intermediates $\mathbf{1 7}$ and 18, which leads to two different transition states $\mathbf{1 9}$ and 20. ${ }^{50,51}$ Of the two possible transition states for the subsequent ligand coupling, the transition state $\mathbf{2 0}$ is more favorable than 19, because both the negative charge on the aromatic ring and the enhanced positive charge on the iodine(III) are stabilized more effectively by the substituents. ${ }^{49}$

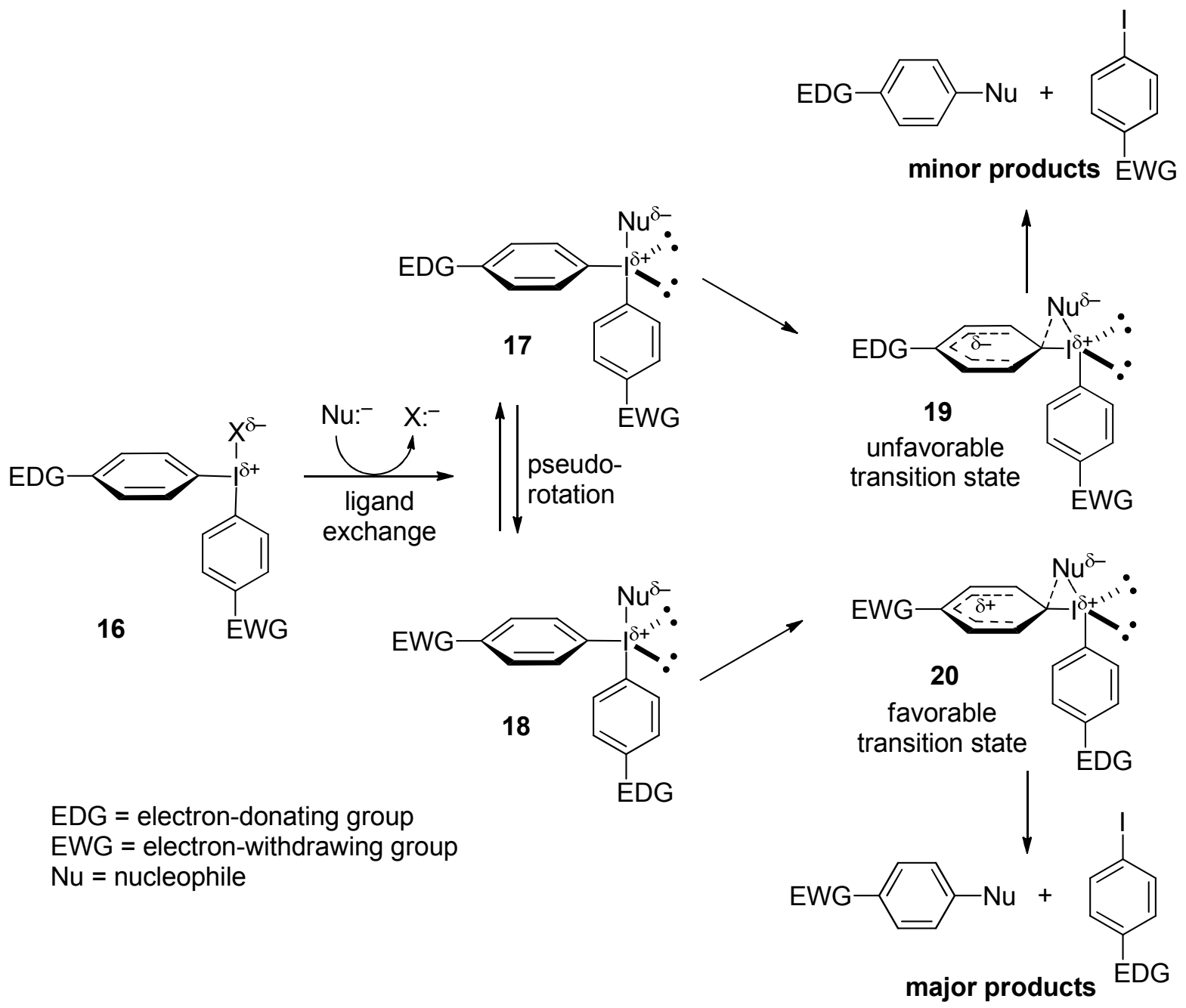

Scheme 8. General mechanistic scheme for the reactions of diaryliodonium salts with nucleophiles. 
The so-called "ortho-effect" is observed in the reactions between a nucleophile and a diaryliodonium salt where one aryl ligand has a bulky ortho-substituent, such as methyl. In these reactions the ortho-substituted aryl ligand is often coupled with the nucleophile, even if it is a more electron-rich aromatic ring. ${ }^{52,53}$ This has been explained by the predominant conformation 21 of the $\operatorname{Ar}(\mathrm{Ph}) \mathrm{INu}$ intermediate with the most bulky aryl ligand and the two lone pairs occupying the equatorial position for steric reasons since the equatorial positions are roomier than the axial positions (Scheme 9). Ligand coupling in the intermediate $\mathbf{2 1}$ leads to a reductive elimination of $\mathrm{PhI}$ and transfer of the nucleophile to the ortho-substituted aryl group situated in the equatorial position, even though it is the more electron-rich aromatic ring.
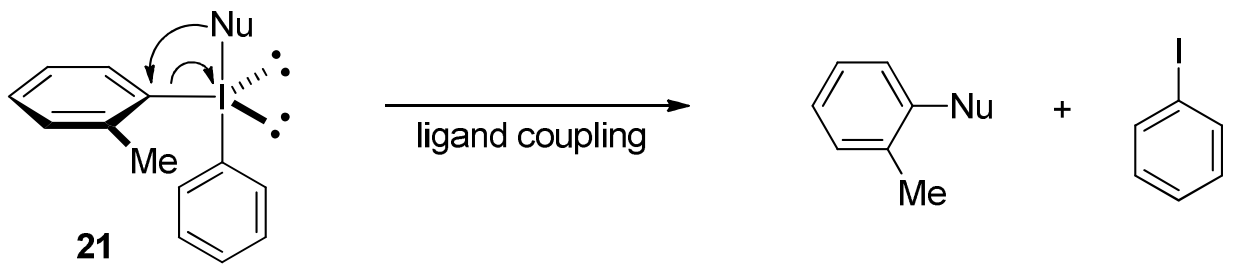

Scheme 9. Explanation of enhanced reactivity of ortho-substituted aryl ligands.

Several mechanistic and structural studies of the nucleophilic fluorination reactions of iodonium salts have been published. ${ }^{54-56}$ DiMagno and co-workers have carried out advanced NMR studies of the interaction of diaryliodonium salts with anhydrous tetramethylammonium fluoride. $^{55}$ These reactions involve the initial anion exchange with the formation of diaryliodonium fluorides, $\mathrm{Ar}_{2} \mathrm{IF}$, followed by ligand coupling as outlined in Scheme 8 . It has been found that the selectivity of nucleophilic fluorination and yields of products can be improved by changing reaction conditions. ${ }^{55}$ In particular, the use of low polarity aromatic solvents (benzene or toluene) and/or the removal of inorganic salts, result in dramatically increased yields of fluorinated arenes from diaryliodonium salts. ${ }^{55}$

It was also found that diaryliodonium salts undergo rapid, fluoride-promoted aryl exchange reactions at room temperature in acetonitrile. ${ }^{54}$ This exchange is highly sensitive to the concentration of fluoride ion in solution; the fastest exchange is observed as the fluoride concentration approaches a stoichiometric amount at $50 \mathrm{mM}$ substrate concentration. It was demonstrated that free fluoride ion or a four-coordinate anionic I(III) species may be responsible for the exchange. ${ }^{54}$ The fluoride-promoted aryl exchange reaction is general and allows direct measurement of the relative stabilities of diaryliodonium salts featuring different aryl substituents.

Lee, Pike, and co-workers have studied the conformational structure and energetics of 2methylphenyl(2'-methoxyphenyl)iodonium chloride. ${ }^{56} \mathrm{X}$-ray structural analysis revealed that this diaryliodonium salt has a conformational dimeric structure with hypervalent iodine as a stereogenic center in each conformer. The LC-MS spectra of this iodonium chloride showed the presence of dimeric and tetrameric anion-bridged clusters in organic solution. These observations 
of the dimeric and higher order clusters of iodonium salts in solution are important for general understanding of the mechanism and outcome of reactions of diaryliodonium salts in organic media with nucleophiles, such as the $\left[{ }^{18} \mathrm{~F}\right]$ fluoride ion. ${ }^{56}$

\subsection{Selectivity of nucleophilic fluorination}

The regioselectivity of the $\left[{ }^{18} \mathrm{~F}\right]$-fluorination reaction is especially important in the reactions of nonsymmetrical iodonium salts (Scheme 10). The distribution of the fluorine-18 containing products depends on the stereoelectronic properties of substituents in the benzene ring; in general, the presence of electron-withdrawing substituents in the aromatic ring is favorable for the introduction of the fluoride nucleophile (see previous section for mechanistic discussion). The problem of low selectivity of the $\left[{ }^{18} \mathrm{~F}\right]$-fluorinations in principle can be solved by modification of electronic and steric properties of substituents $\mathrm{R}^{1}$ and $\mathrm{R}^{2}$ and by optimizing the reaction conditions.
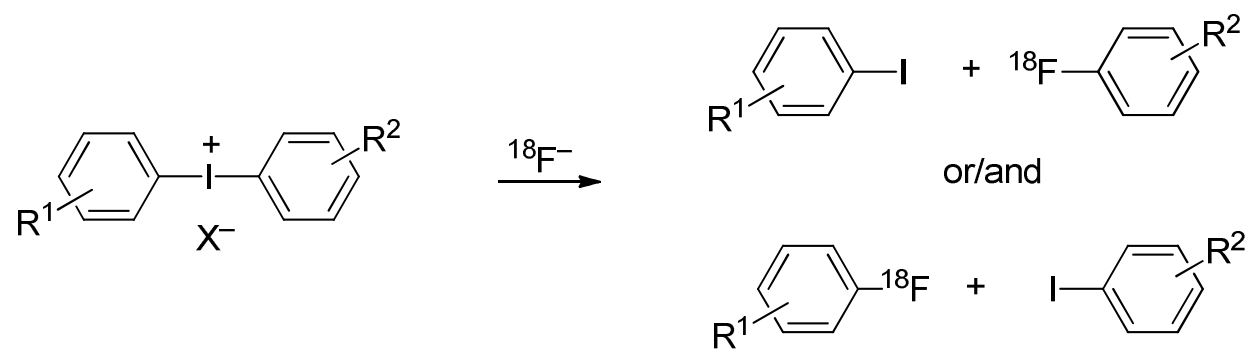

Scheme 10. Nucleophilic $\left[{ }^{18} \mathrm{~F}\right]$-fluorination of nonsymmetrical iodonium salts.

The synthesis of aryl fluorides by thermal decomposition of diaryliodonium tetrafluoroborates was first reported by Van der Puy in 1982. ${ }^{57}$ It was found that reactions of diphenyliodonium salts, $\mathrm{Ph}_{2} \mathrm{I}^{+} \mathrm{X}^{-}$, with different anions $\left(\mathrm{X}=\mathrm{BF}_{4}, \mathrm{CF}_{3} \mathrm{CO}_{2}\right.$, TsO, $\left.\mathrm{Cl}\right)$ upon heating with $\mathrm{KF}$ in DMF afford fluorobenzene in $11-85 \%$ yield. The lowest yield of fluorobenzene $(11 \%)$ was observed in the reaction of diphenyliodonium chloride with $\mathrm{KF}$ in $\mathrm{DMF}$ at $115{ }^{\circ} \mathrm{C}$, while the thermolysis of $\mathrm{Ph}_{2} \mathrm{I}^{+} \mathrm{BF}_{4}^{-}$in the presence of $\mathrm{KF}$ at $160-170{ }^{\circ} \mathrm{C}$ without solvent gave $\mathrm{PhF}$ in $85 \%$ yield. The formation of benzene (2-9\%) due to a parallel radical decomposition process was also observed in all these reactions. ${ }^{57}$

In 1995 Pike and Aigbirhio applied diaryliodonium salts for the preparation of ${ }^{18} \mathrm{~F}$-labeled aryl fluorides for the first time, using potassium $\left[{ }^{18} \mathrm{~F}\right]$-fluoride in the presence of diazacrown ether Kryptofix $\left(\mathrm{K}_{2.2 .2}\right.$; structure 1 in Scheme 1) in acetonitrile at $85{ }^{\circ} \mathrm{C}$ or $110{ }^{\circ} \mathrm{C} .{ }^{35}$ Under these conditions, the reaction of diphenyliodonium chloride provided $\left[{ }^{18} \mathrm{~F}\right]$-fluorobenzene in $31-78 \%$ radiochemical yield. The use of Kryptofix is required for the phase transfer of the $\left[{ }^{18} \mathrm{~F}\right]$-fluoride ion obtained by the nuclear reaction in the cyclotron as a solution in water enriched with oxygen18.

Further investigations have shown that the regioselectivity of $\left[{ }^{18} \mathrm{~F}\right]$-fluorination is controlled by electronic factors and by the bulk of the ortho-substituents on the rings, with the latter being 
the dominant factor. Pike and co-workers have reported a detailed study of the reactions of several ortho-substituted iodonium salts with $\left[{ }^{18} \mathrm{~F}\right]$-fluoride in acetonitrile at $85{ }^{\circ} \mathrm{C}{ }^{58}$ It was found that the electronic effects of substituents on aromatic rings in radiochemical nucleophilic fluorination processing are similar to the reactions of iodonium salts with other nucleophiles, and fluorine-18 is introduced to the aromatic ring containing electron-withdrawing substituents. However, the presence of a bulky ortho-substituent changes the regioselectivity allowing fluorination of the electron-rich ortho-substituted ring. For example, the reaction of 2,4,6trimethylphenyl(phenyl)iodonium triflate 22 with the complex of potassium $\left[{ }^{18} \mathrm{~F}\right]$-fluoride with Kryptofix exclusively affords 1-fluoro-2,4,6-trimethylbenzene $\mathbf{2 3}$ along with iodobenzene as a byproduct (Scheme 11). ${ }^{58}$

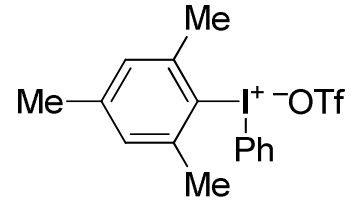

22

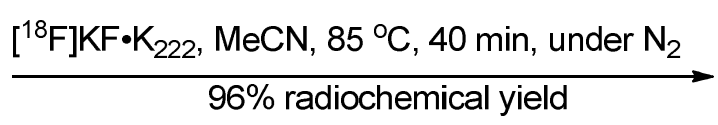

$96 \%$ radiochemical yield

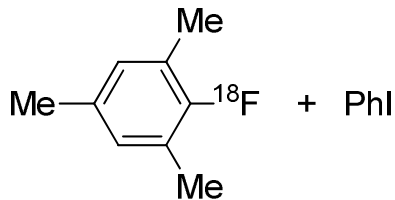

23

Scheme 11. Effect of a bulky ortho-substituent on the regioselectivity of fluorination.

Carroll and co-workers have published a series of papers on applications of aryliodonium salts for the preparation of fluorine-containing aromatic and heteroaromatic products. ${ }^{31,59,60}$ In particular, it has been found that the addition of radical scavengers such as TEMPO $(2,2,6,6-$ tetramethylpiperidine-1-oxyl) to the reaction mixture leads to a significant improvement of both the reproducibility of the process and the material yield of the desired fluoroarene products without affecting the regioselectivity of the process. ${ }^{59}$ For example, the reaction of iodonium salt 24 with cesium fluoride in different solvents (DMF, DMSO, acetonitrile, $N, N$ dimethylacetamide) in the absence of a radical trap affords a mixture of fluoroarenes 25 and 26 in the ratio 1:1 with combined yield below 5\%. Carrying out this reaction in the presence of 20 mol\% TEMPO leads to increased yields of $\mathbf{2 5}$ and $\mathbf{2 6}$ up to 35\% with almost unchanged regioselectivity (Scheme 12). ${ }^{59}$ This methodology is potentially applicable in the production of fluorine-18 labeled radiopharmaceuticals including L-6- $\left[{ }^{18} \mathrm{~F}\right]$ fluoroDOPA $27,{ }^{61}$ which is an important radioligand for the study of brain dopaminergic neuron density in movement disorders, such as Parkinson's disease. 


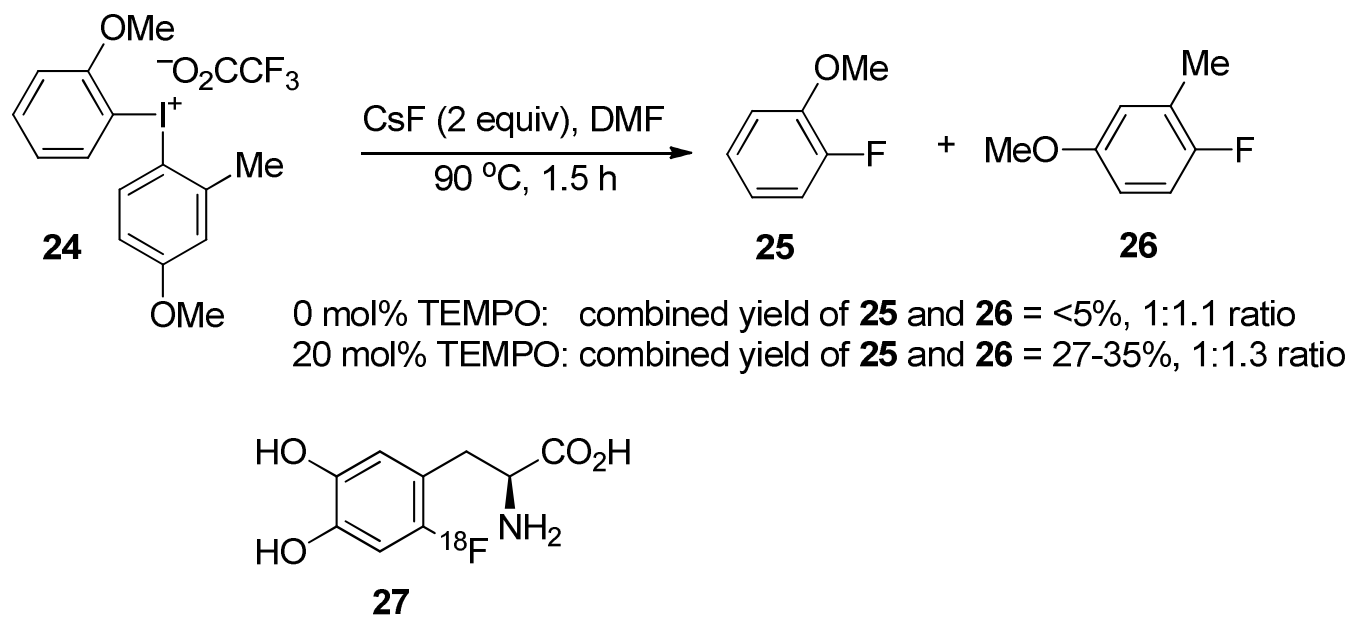

Scheme 12. Effect of TEMPO on the reaction of iodonium salts with fluoride anion.

DiMagno and co-workers have found that exceptionally electron-rich arene rings can be fluorinated with high regioselectivity by the reductive elimination reactions of 5methoxy[2.2]paracyclophan-4-yl iodonium salt 28 (Scheme 13). ${ }^{62,63}$ Application of the sterically hindered cyclophane directing group allows a high degree of control in fluorination reactions of diaryliodonium salts. However, despite excellent selectivity, this approach has obvious disadvantages, such as the use of inaccessible starting compounds and complex synthetic procedures.

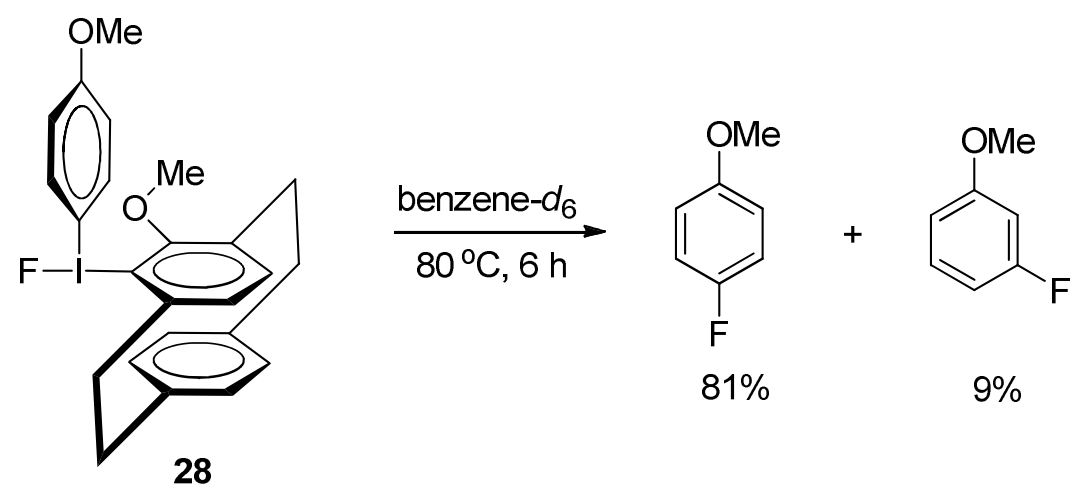

Scheme 13. Regioselective fluorination of 5-methoxy[2.2]paracyclophan-4-yl iodonium salt.

\subsection{Reactions of aryl(heteroaryl)iodonium salts with fluoride anion}

Extensive studies of fluorination reactions of different classes of heteroaromatic iodonium salts have been performed by several research groups. ${ }^{31,60,64-66}$ In general, a theoretical prediction that the nucleophilic substitution in the electron-rich aryl(heteroaryl)iodonium salts by fluoride ion is regioselective for the aryl ring has been confirmed by experimental observation. ${ }^{64}$ Coenen and co-workers have reported an efficient procedure for nucleophilic fluorination using aryl-(2- 
thienyl)iodonium salts 29 (Scheme 14). ${ }^{65}$ The 2-thienyl group is a highly electron-rich group that allows the introduction of ${ }^{18} \mathrm{~F}$ directly into even electron-rich arenes like anisoles. It has also been found that the selectivity of the fluorination of iodonium salts $\mathbf{2 9}$ depends on the nature of the counteranion $\mathrm{X}^{-}$, with the highest yields of $\mathrm{Ar}^{18} \mathrm{~F}$ (up to $60 \%$ radiochemical yield) achieved in the reactions of iodonium bromides. ${ }^{65}$

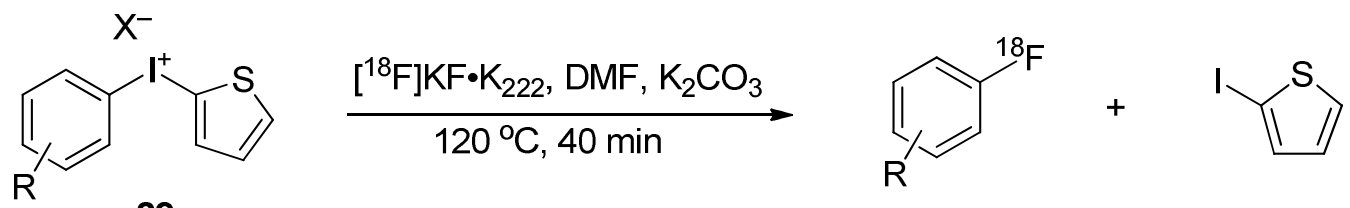

29

$\mathrm{R}=$ 2-OMe, 3-OMe, 4-OMe, 4-OBn, $\mathrm{H}, 4-\mathrm{I}, 4-\mathrm{Br}, 4-\mathrm{Cl}$

$\mathrm{X}=\mathrm{Br}, \mathrm{I}$, OTs, OTf

Scheme 14. Regioselective nucleophilic fluorination of aryl-(2-thienyl)iodonium salts reported by Coenen and co-workers. ${ }^{65}$

In contrast to Coenen's results, ${ }^{65}$ a detailed study of nucleophilic fluorination of aryl(thienyl)iodonium salts by Carroll and co-workers has demonstrated a very low selectivity of this reaction producing a mixture of six products as illustrated in Scheme $15{ }^{60}$ The authors suggested that the previous reports on the absence of 2-fluorothiophene among the reaction products of aryl-(2-thienyl)iodonium salts were misleading. This lack of detection may be due the highly volatile nature of 2-fluorothiophene (boiling point $82{ }^{\circ} \mathrm{C}$ ), which may be lost under the reaction conditions or on work-up/analysis. ${ }^{60}$

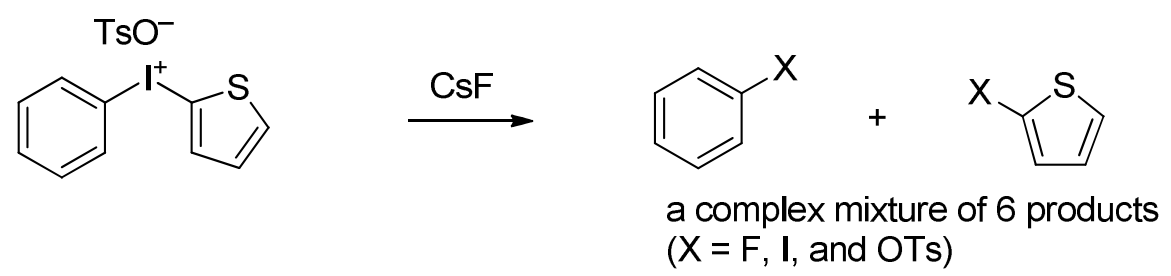

Scheme 15. Low selectivity in nucleophilic fluorination of phenyl-(2-thienyl)iodonium tosylate reported by Carroll and co-workers. ${ }^{60}$

Onys'ko, Gakh and co-workers have demonstrated that a selective synthesis of 2fluorothiophene can be accomplished by heating bis(2-thienyl)iodonium salts with potassium fluoride. ${ }^{66}$ In particular, the treatment of bis(2-thienyl)iodonium hexafluorophosphate 30 with potassium fluoride (as a mechanical mixture) at $172-175{ }^{\circ} \mathrm{C}$ for 2 hours afforded 2fluorothiophene, 2-iodothiophene, and thiophene (Scheme 16). Bis(2-thienyl)iodonium salts with more nucleophilic anions, such as trifluoroacetate, yielded only trace amounts of the desired 2fluorothiophene. ${ }^{66}$ 


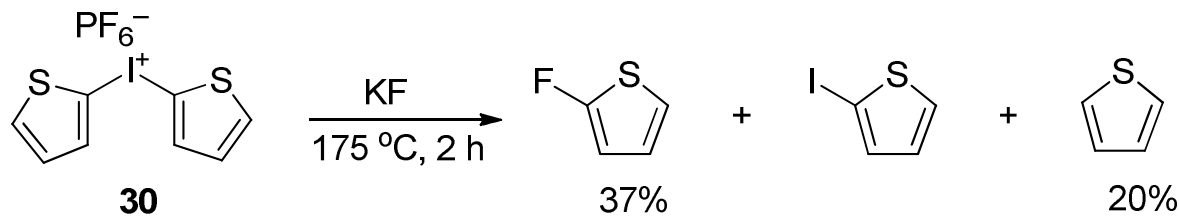

Scheme 16. Synthesis of 2-fluorothiophene.

Carroll and co-workers have developed a convenient and selective route to fluorine-18 labeled 3-fluoropyridine 32 and 3-fluoroquinoline 34 by $\left[{ }^{18} \mathrm{~F}\right]$-fluorination of iodonium salts 31 and 33 (Scheme 17). ${ }^{31}$ The use of 4-methoxyphenyl as the aryl group in aryl(heteroaryl)iodonium salts $\mathbf{3 1}$ and $\mathbf{3 3}$ provides the necessary degree of selectivity in the nucleophilic fluorination process. Fluorine-18 labeled fluoropyridines have found increasing applications in the medical imaging technique of PET. ${ }^{31}$<smiles>[X][I+](c1ccc(OC)cc1)c1cccnc1</smiles>

31<smiles>[X][I+](c1ccc(OC)cc1)c1cnc2ccccc2c1</smiles>

33

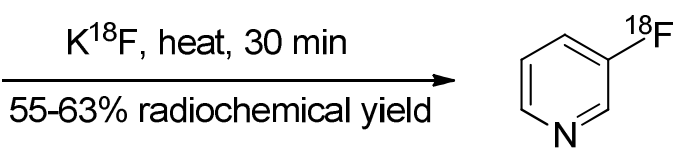

32<smiles>Fc1cnc2ccccc2c1</smiles>
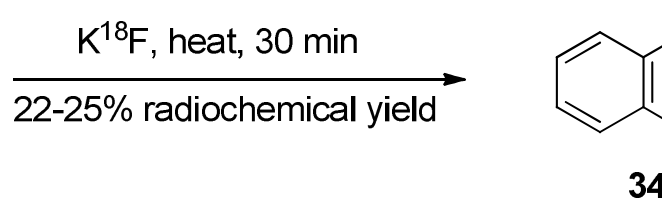

$\mathrm{X}=$ OTs or OTf

Scheme 17. Preparation of fluorine-18 labeled 3-fluoropyridine and 3-fluoroquinoline.

\subsection{Preparation of specific PET radioligands using diaryliodonium salts as precursors}

Numerous reports on the optimization of the $\left[{ }^{18} \mathrm{~F}\right]$-fluorinations and the preparation of specific $\left[{ }^{18} \mathrm{~F}\right]$-labeled radiotracers using diaryliodonium salts have been published. Wüst and co-workers have developed a convenient access to 4-[ $\left.{ }^{18} \mathrm{~F}\right]$ fluoroiodobenzene 36 employing 4,4'diiododiaryliodonium salt $\mathbf{3 5}$ as a precursor (Scheme 18). ${ }^{67-69} 4-\left[{ }^{18}\right.$ F]Fluoroiodobenzene $\mathbf{3 6}$ has been further utilized in Sonogashira or Stille cross-coupling reactions for the preparation of numerous radiotracers. For example, the Stille reaction with $4-\left[{ }^{18} \mathrm{~F}\right]$ fluoroiodobenzene has been used for the synthesis of radiotracers for monitoring COX-2 expression by means of PET. By using optimized reaction conditions ${ }^{18}$ F-labelled COX-2 inhibitors $\mathbf{3 7}$ and $\mathbf{3 8}$ could be obtained in radiochemical yields of up to $94 \%$ and $68 \%$, respectively, based upon 4$\left[{ }^{18} \mathrm{~F}\right]$ fluoroiodobenzene $\mathbf{3 6} .{ }^{68}$ 


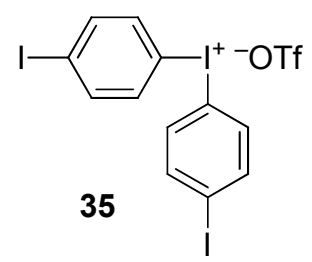

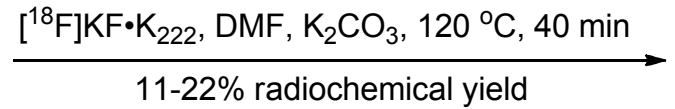
$\frac{\mathrm{PdCl}_{2}\left(\mathrm{PPh}_{3}\right)_{2}, \mathrm{Cul}, \mathrm{DMF}, 50^{\circ} \mathrm{C}}{94 \%}$

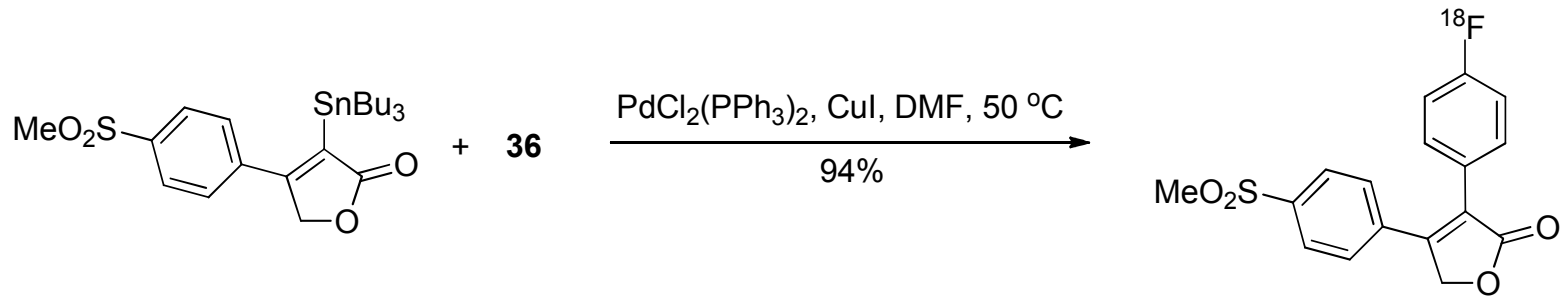

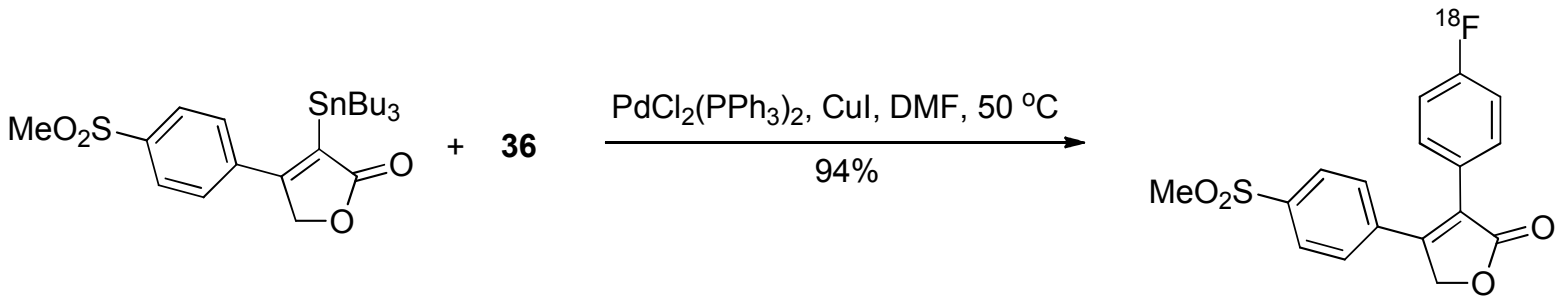<smiles>Ic1ccc(I)cc1</smiles>

36

37

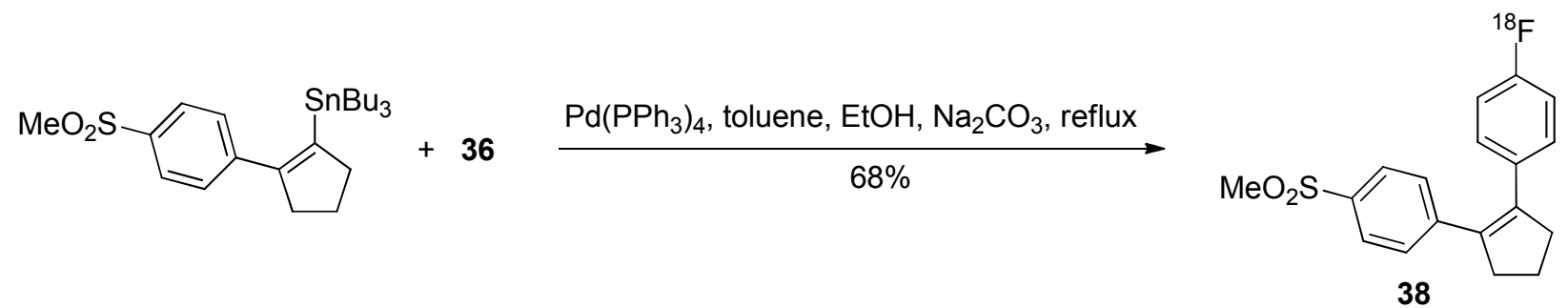

Scheme 18. Synthesis of $4-\left[{ }^{18} \mathrm{~F}\right]$ fluoroiodobenzene $\mathbf{3 6}$ and its use in cross-coupling reactions for the preparation of radiotracers $\mathbf{3 7}$ and $\mathbf{3 8}$.

Zhang and co-workers have synthesized a PET ligand $\left[{ }^{18} \mathrm{~F}\right] \mathrm{DAA} 1106$ (compound 40) from diaryliodonium salt 39 with the radioactive $\left[{ }^{18} \mathrm{~F}\right]$-fluoride anion (Scheme 19) ${ }^{70} \mathrm{It}$ is essential that the electron-rich 4-methoxyphenyl is present as the second aromatic substituent in iodonium salt $39\left(\mathrm{Ar}=4-\mathrm{MeOC}_{6} \mathrm{H}_{4}\right)$; the reaction of analogous phenyliodonium salt $(\mathbf{3 9}, \mathrm{Ar}=\mathrm{Ph})$ gave desired product $\mathbf{4 0}$ in only $3 \%$ yield. Compound $\mathbf{4 0}$ is used as a PET ligand for imaging a peripheral-type benzodiazepine receptor. ${ }^{70}$

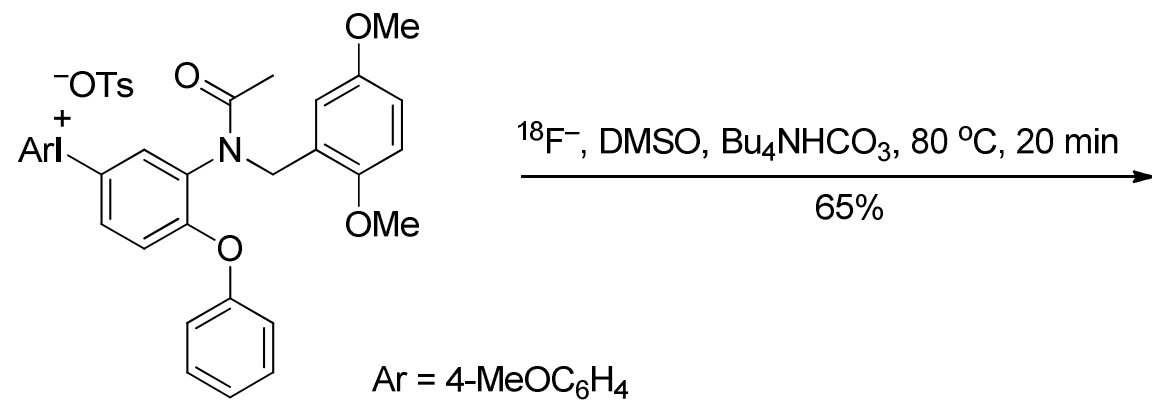

39<smiles>COc1ccc(OC)c(CN(C(C)=O)c2cc(C(F)(F)F)ccc2Oc2ccccc2)c1</smiles>

$71: 29$ ratio

Scheme 19. Synthesis of PET ligand $\left[{ }^{18} \mathrm{~F}\right] \mathrm{DAA} 1106$ (compound 40). 
Katzenellenbogen and co-workers have reported the synthesis and evaluation of two ${ }^{18} \mathrm{~F}$ labeled analogues of the potent and selective PPAR $\gamma$ agonist farglitazar. ${ }^{71,72}$ In particular, the radioligand 42 was prepared by nucleophilic fluorination of phenyliodonium salt $\mathbf{4 1}$ in good radiochemical yield (Scheme 20). ${ }^{71}$ Interestingly, the reactions of iodonium salts $\mathbf{4 1}$ bearing the 3-methoxyphenyl or 2-thienyl substituents instead of the phenyl did not afford any fluorinated product 42.
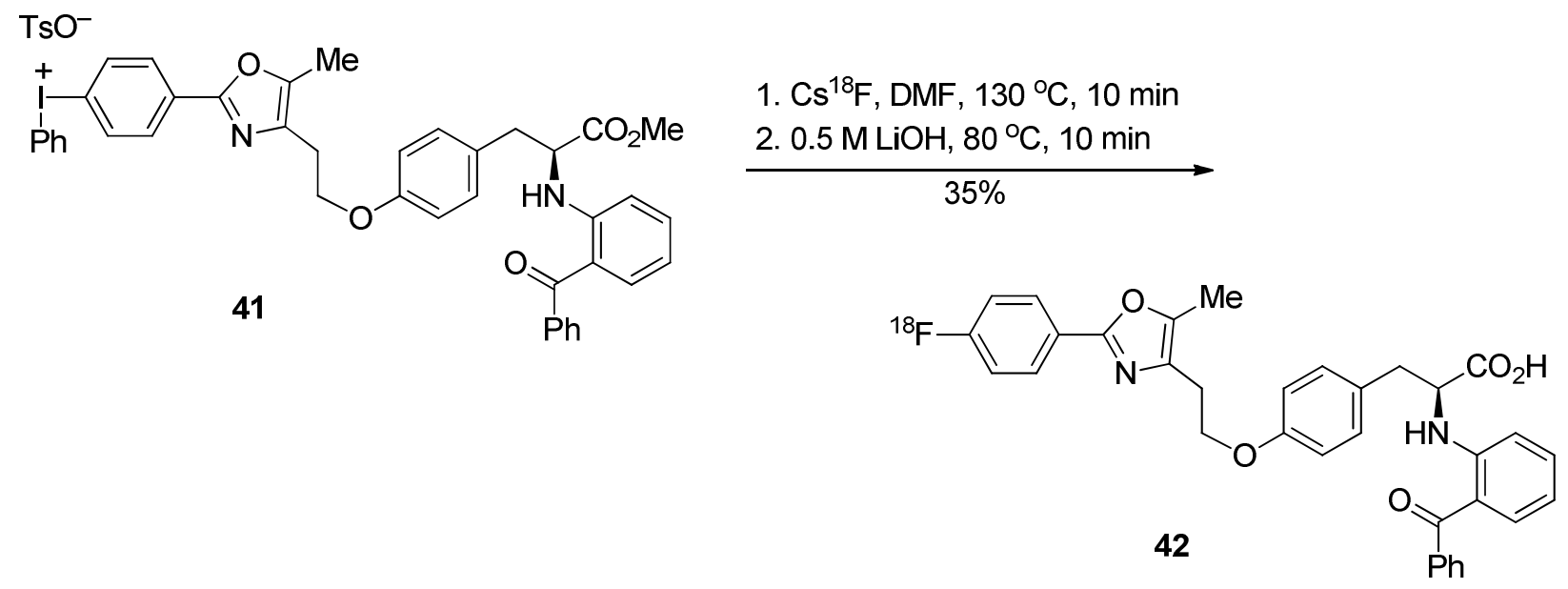

Scheme 20. Synthesis of the ${ }^{18}$ F-labeled analogue of PPAR $\square$ agonist farglitazar.

Pike and co-workers have investigated the applicability of nucleophilic radiofluorination of diaryliodonium salts for the preparation of otherwise difficult to access meta-substituted $\left[{ }^{18} \mathrm{~F}\right]$ fluoroarenes. ${ }^{42,45}$ These studies have resulted in the developement of a synthetic approach to 3-fluoro-1-[(thiazol-4-yl)ethynyl]benzenes $\mathbf{4 3}$ through the radiofluorination of diaryliodonium tosylates 10 (Scheme 21). ${ }^{45}$ 3-Fluoro-1-[(thiazol-4-yl)ethynyl]benzenes constitute an important class of high-affinity metabotropic glutamate subtype 5 receptor (mGluR5) ligands; fluorine-18 labeled compounds $\mathbf{4 3}$ are used as radioligands for molecular imaging of brain mGluR5 in living animal and human subjects with PET. ${ }^{45}$
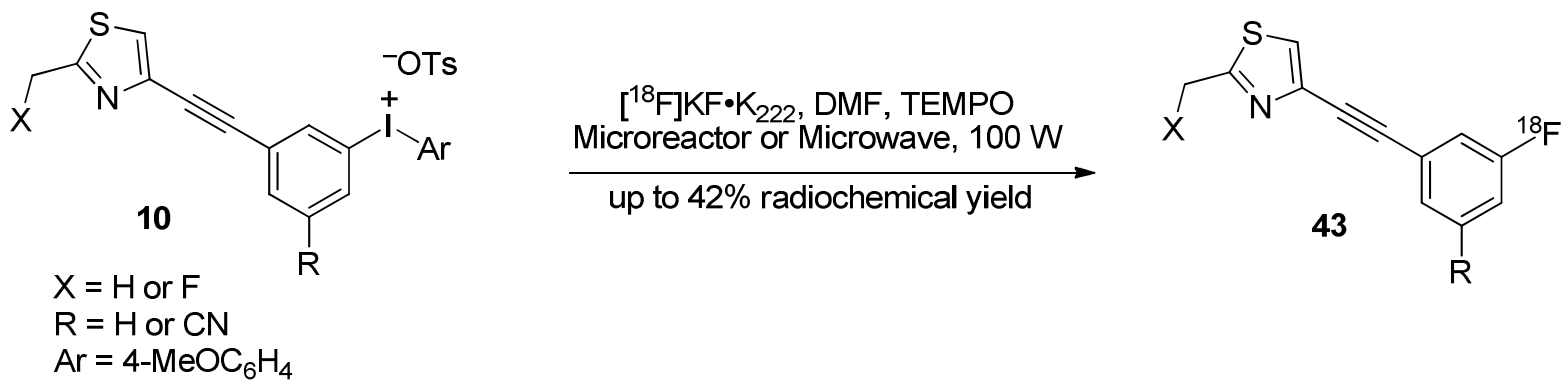

Scheme 21. Synthesis of ${ }^{18}$ F-labeled 3-fluoro-1-[(thiazol-4-yl)ethynyl]benzenes. 
Chun and Pike have developed a rapid, single-step radiosynthesis of azido- or azidomethylsubstituted $\left[{ }^{18} \mathrm{~F}\right]$ fluoroarenes 45 and $\mathbf{4 7}$ by the reaction of diaryliodonium salts 44 or $\mathbf{4 6}$ with nocarrier-added $\left[{ }^{18} \mathrm{~F}\right]$ fluoride ion within a microfluidic apparatus to synthesize previously poorly accessible ${ }^{18}$ F-labeled click synthons in good radiochemical yields (Scheme 22). ${ }^{73}$ The radiosynthesis of synthons $\mathbf{4 7}$ was also possible with "wet" cyclotron-produced NCA $\left[{ }^{18} \mathrm{~F}\right]$ fluoride ion, in the presence of about $70 \mathrm{vol}-\%$ water, thus eliminating the need to dry the cyclotron-produced $\left[{ }^{18} \mathrm{~F}\right]$ fluoride ion and greatly enhancing the practicality of the method. ${ }^{73}$

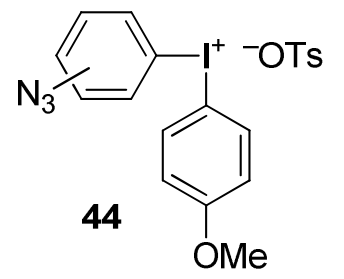

$$
\underset{10-15 \% \text { radiochemical yield }}{\stackrel{\left[{ }^{18} \mathrm{~F}\right] \mathrm{KF} \cdot \mathrm{K}_{222}}{\mathrm{D}} \mathrm{DMF}, 160^{\circ} \mathrm{C}, 3 \mathrm{~min}}
$$

$\mathrm{N}_{3}$-group in $m$-or $p$-position

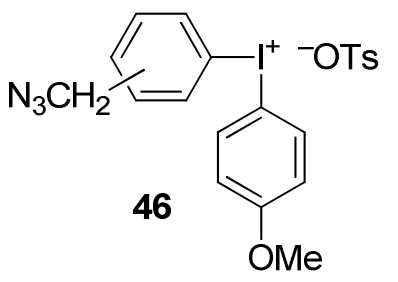

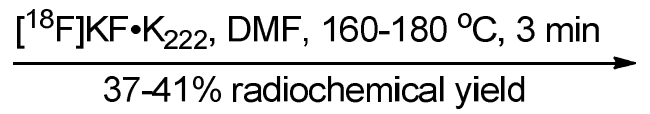

$\mathrm{CH}_{2} \mathrm{~N}_{3}$-group in o-, $m$ - or $p$-position

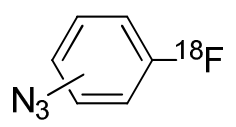

45

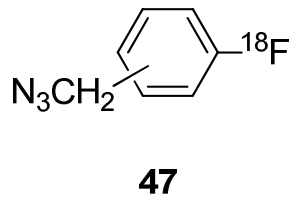

Scheme 22. Radiosynthesis of azido- or azidomethyl-substituted $\left[{ }^{18} \mathrm{~F}\right]$ fluoroarenes.

Griffiths and co-workers reported the synthesis and characterization of phenyl(3formylphenyl)iodonium salts containing four different counter anions, $\mathrm{TfO}^{-}, \mathrm{Cl}^{-}, \mathrm{Br}^{-}, \mathrm{TsO}^{-}$, and the nucleophilic ${ }^{18} \mathrm{~F}$-fluorination of these iodonium salts leading to $m-\left[{ }^{18} \mathrm{~F}\right]$ fluorobenzaldehyde and $m$ - $\left[{ }^{18} \mathrm{~F}\right]$ fluorobenzylbromide. ${ }^{48}$ In particular, $m$ - $\left[{ }^{18} \mathrm{~F}\right]$ fluorobenzaldehyde was prepared by the

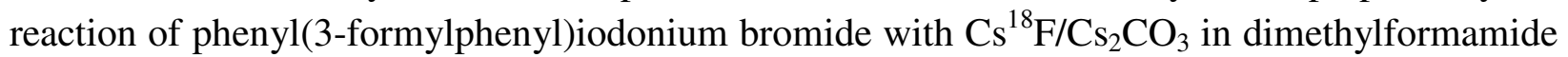
at $100{ }^{\circ} \mathrm{C}$ for $5 \mathrm{~min}$ in a microwave in the presence of one equivalent of TEMPO. ${ }^{48}$ The obtained $3-\left[{ }^{18} \mathrm{~F}\right]$ fluorobenzaldehyde was further reduced to benzyl alcohol and converted into $3-\left[{ }^{18} \mathrm{~F}\right]$ fluorobenzyl bromide. $3-\left[{ }^{18} \mathrm{~F}\right]$ fluorobenzyl bromide was subsequently used in the synthesis of ${ }^{18} \mathrm{~F}$-radiolabeled lapatinib, a potential tracer for positron emission tomographic imaging of ErbB1/ErbB2 tyrosine kinase activity. ${ }^{74}$

Kim and co-workers have developed agents for radionuclide imaging $\beta$-amyloid plaques in vivo based on fluorine-substituted arylbenzothiazoles 49 (Scheme 23). 2-Aryl-6$\left[{ }^{18} \mathrm{~F}\right]$ fluorobenzothiazoles 49 were synthesized from diaryliodonium tosylate precursors 48 in efficiently short reaction times $(40-60 \mathrm{~min})$ in high radiochemical yields, with purities above $95 \%$ and specific activities of $85-118 \mathrm{GBq} / \mu \mathrm{mol} .{ }^{46}$ 


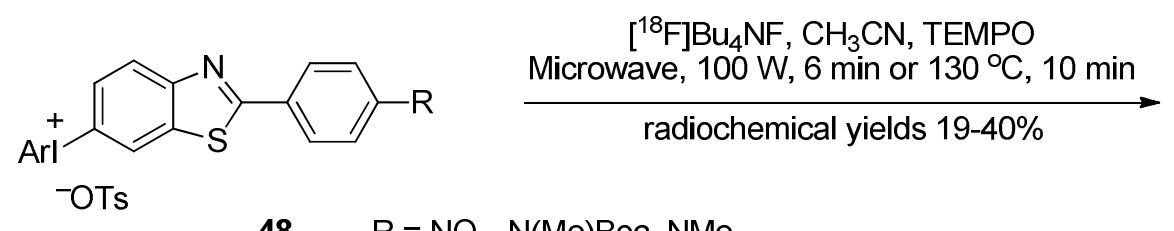

$48 \quad \mathrm{R}=\mathrm{NO}_{2}, \mathrm{~N}(\mathrm{Me}) \mathrm{Boc}, \mathrm{NMe}_{2}$

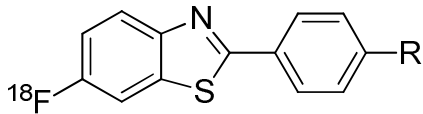

49

Scheme 23. Radiosynthesis of 2-aryl-6-[ ${ }^{18}$ F]fluorobenzothiazoles.

Aromatic radiofluorination of the diaryliodonium tosylate precursor 13 with $\left[{ }^{18} \mathrm{~F}\right]$ fluoride ions has been applied successfully to access $\left[{ }^{18} \mathrm{~F}\right]$ flumazenil $\mathbf{5 0}$ in high radiochemical yields (Scheme 24). ${ }^{47}$ Radioisotope labeled flumazenil is an important radiopharmaceutical product for the assessment of the central benzodiazepine receptor (cBZR) concentration in the brain. It was found that the stability and reactivity of the diaryliodonium tosylate precursor $\mathbf{1 3}$ plays a key role in increasing the yield of fluorinated product 50. This reaction was extended to a viable method for use in automated synthesis with an average radiochemical yield of $64 \%$ within 60 min. $\left[{ }^{18}\right.$ F]Flumazenil $\mathbf{5 0}$ was isolated by preparative HPLC after the reaction was conducted under improved conditions and exhibited sufficient specific activity of 370-450 GBq/ $\mu \mathrm{mol}$, with a radiochemical purity of $>99 \%$, which is suitable for human PET studies. ${ }^{47}$

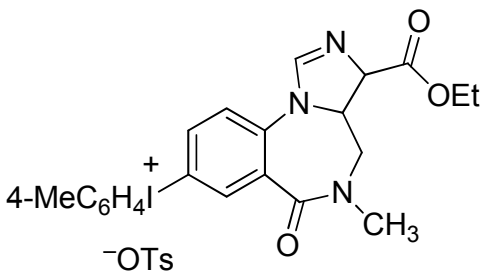

13

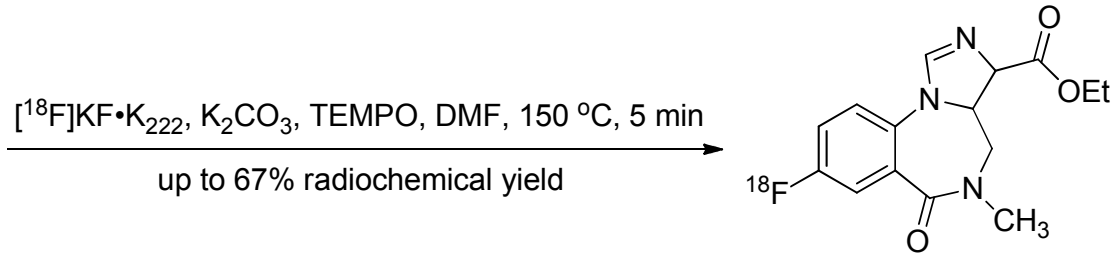

50

Scheme 24. Radiosynthesis of $\left[{ }^{18} \mathrm{~F}\right]$ flumazenil $\mathbf{5 0}$.

\section{Iodonium Ylides as Reagents for Nucleophilic Fluorination}

The use of iodonium ylides as PET precursors for labeling reactions with fluorine-18 has recently been described in a patent. ${ }^{75}$ Like the reactions of iodonium salts as precursors, even electron-rich fluoroarenes can be prepared using aryl iodonium ylides and nucleophilic nocarrier-added $\left[{ }^{18} \mathrm{~F}\right]$ fluoride anion. However, in contrast to the reactions of diaryliodonium salts, the reactions of the iodonium ylides have been claimed to be regiospecific. ${ }^{75}$

Aryliodonium ylides, $\mathrm{ArI}^{+}-{ }^{-} \mathrm{CX}_{2}$, where $\mathrm{X}$ is an electron-withdrawing substituent (e.g., carbonyl or sulfonyl group), represent an important class of iodonium compounds, in which a carbon with carbanionic character is present. ${ }^{2}$ Due to this charge distribution, the attack of the external nucleophile should be directed exclusively toward the aromatic ring of the Ar group, 
which makes aryliodonium ylides attractive candidates for use as labeling precursors of $\left[{ }^{18} \mathrm{~F}\right]$ fluoroarenes.

The first example of a stable phenyliodonium ylide derived from dimedone (5,5-dimethyl1,3-cyclohexanedione) was reported by Neiland and co-workers in $1957 .{ }^{76}$ Since then, numerous stable aryliodonium ylides have been prepared and structurally investigated. Single X-ray crystallographic studies demonstrate that the geometry of aryliodonium ylides is similar to the geometry of iodonium salts with a C-I-C angle close to $90^{\circ}$, which is indicative of a zwitterionic nature in the ylidic $\mathrm{C}-\mathrm{I}$ bond. The chemistry of aryliodonium ylides has been summarized in several reviews mainly devoted to their use as precursors for generation of singlet carbene or carbenoid species. $^{77-80}$

\subsection{Preparation and properties of iodonium ylides}

Most iodonium ylides have a relatively low thermal stability and can be handled only at low temperature or generated and used in situ. The relatively stable and practically important iodonium ylides, the dicarbonyl derivatives $\mathrm{PhIC}(\mathrm{COR})_{2},{ }^{76,81-84}$ and bis(organosulfonyl)(phenyliodonium)methanides, $\mathrm{PhIC}\left(\mathrm{SO}_{2} \mathrm{R}\right)_{2},{ }^{85-88}$ are prepared by a reaction of (diacetoxyiodo)benzene with the appropriate dicarbonyl compound or disulfone under basic conditions. A general procedure for the synthesis of phenyliodonium ylides $\mathbf{5 2}$ from malonate esters $\mathbf{5 1}$ is based on the treatment of esters $\mathbf{5 1}$ with (diacetoxyiodo)benzene in dichloromethane in the presence of potassium hydroxide (Scheme 25) ${ }^{83}$ An optimized method for preparing bis(methoxycarbonyl)(phenyliodonium)methanide $\left(\mathbf{5 2}, \mathrm{R}^{1}=\mathrm{R}^{2}=\mathrm{Me}\right)$ using a similar reaction of dimethyl malonate ester with $\mathrm{PhI}(\mathrm{OAc})_{2}$ and $\mathrm{KOH}$ in acetonitrile solution was published in Organic Syntheses in $2010 .{ }^{89}$ Ylides 52 decompose slowly at room temperature but they can be kept for several weeks in a refrigerator.
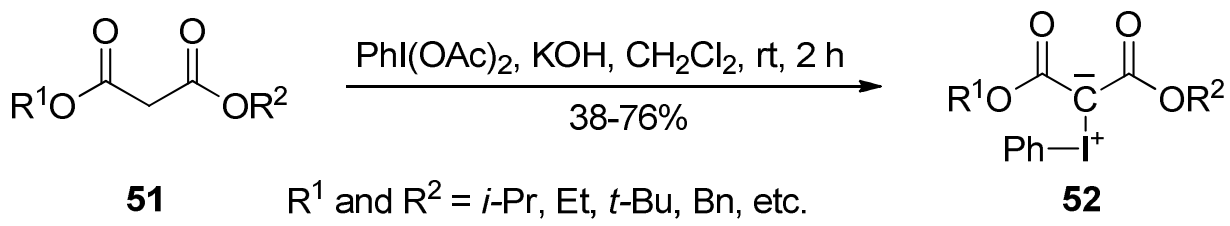

Scheme 25. Preparation of phenyliodonium ylides.

Phenyliodonium ylides $\mathbf{5 2}$ have found some synthetic use as efficient carbene precursors, especially useful as reagents for cyclopropanation of alkenes. Practical applications of ylides $\mathbf{5 2}$ are, however, limited by their poor solubility (insoluble in most organic solvents except DMSO) and low stability. 2-Alkoxyphenyliodonium ylides 54 derived from dialkyl malonates and bearing an ortho alkoxy substituent on the phenyl ring, can be synthesized from commercially available 2-iodophenol according to the procedure shown in Scheme 26. Ylides 54 are relatively stable compounds, have good solubility in dichloromethane, chloroform, or acetone (e.g., the solubility of ylide $54, \mathrm{R}=\mathrm{Pr}$, in dichloromethane is $0.56 \mathrm{~g} / \mathrm{mL}$ ), and have higher reactivity than 
common phenyliodonium ylides in the $\mathrm{Rh}$-catalyzed cyclopropanation, $\mathrm{C}-\mathrm{H}$ insertion, and transylidation reactions under homogeneous conditions. ${ }^{90}$ Higher thermal stability and a useful reactivity pattern are also characteristic of the dimedone-derived $o$-alkoxyphenyliodonium ylides 56, which are prepared similarly by the reaction of diacetates $\mathbf{5 3}$ with dimedone $\mathbf{5 5}$ in methanol in the presence of $\mathrm{KOH}$ at $0{ }^{\circ} \mathrm{C} .{ }^{91}$<smiles>Oc1ccccc1I</smiles>

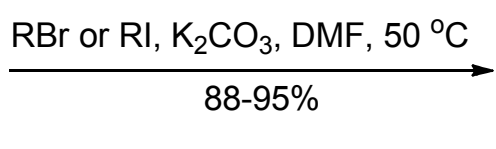

$\mathrm{R}=\mathrm{Me}, n-\operatorname{Pr}, i-\operatorname{Pr}, n-\mathrm{Bu}$

53

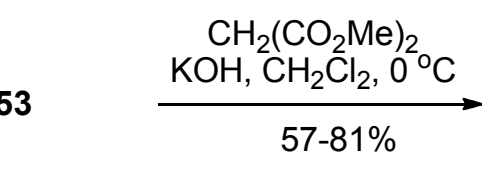<smiles>[R6]c1ccccc1I</smiles>

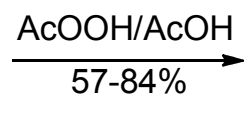

$57-84 \%$

$\mathrm{RO}$<smiles>O=C(O)c1ccccc1I</smiles>

53<smiles>[R6]Oc1ccccc1[I+][C-](Cl)Cl</smiles>

54

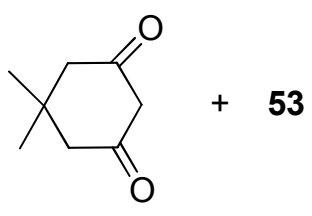

55

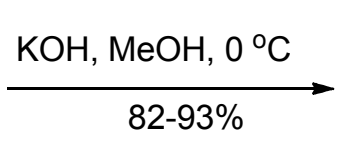

$82-93 \%$

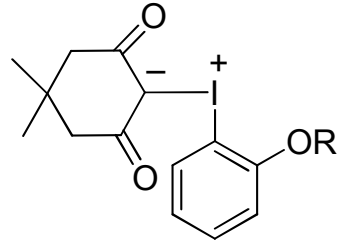

56

Scheme 26. Synthesis of 2-alkoxyphenyliodonium ylides.

Cardinale and Ermert have developed a simplified procedure for the synthesis of aryliodonium ylides directly from the respective aryliodides. ${ }^{84}$ In particular, aryliodonium-(5[2,2-dimethyl-1,3-dioxane-4,6-dione]) ylides 58 were synthesized by the two-step one-pot procedure shown in Scheme 27. Aryl iodides 57 were first oxidized with $m$-chloroperoxobenzoic acid ( $m \mathrm{CPBA}$ ) in dichloromethane, and subsequently a suspension containing Meldrum's acid and $\mathrm{KOH}$ was added to the reaction mixture to afford ylides $\mathbf{5 8}$ in moderate yields. ${ }^{84}$ 


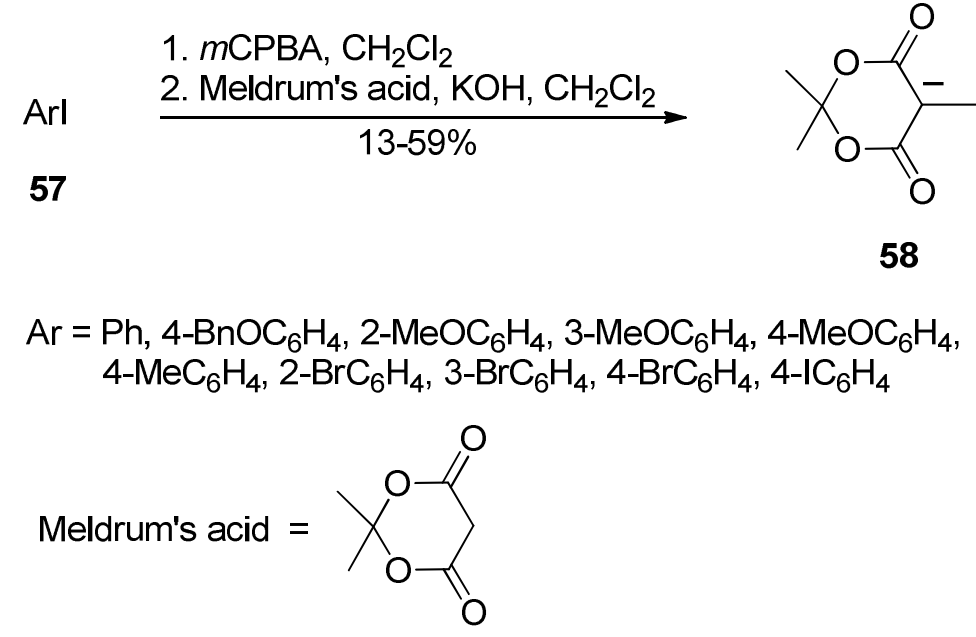

Scheme 27. Simplified one-pot procedure for the synthesis of iodonium ylides.

\subsection{Reactions of iodonium ylides with fluoride anion}

Due to the carbanionic character of the ylidic carbon, the attack of an external nucleophile in principle should be directed exclusively toward the aromatic ring of the Ar group of an aryliodonium ylide. However, it was previously demonstrated that the reaction of various organic and inorganic acids with phenyliodonium ylides leads to nucleophilic substitution of the iodobenzene substituent by the anion. ${ }^{92,93}$ Gondo and Kitamura have recently reported that the reaction of iodonium ylides $\mathbf{5 9}$ derived from 1-phenylbutan-1,3-dione, ethyl benzoylacetate, and ethyl $p$-nitrobenzoylacetate with $\mathrm{Et}_{3} \mathrm{~N} \cdot 3 \mathrm{HF}$ gave the corresponding fluorinated products $\mathbf{6 0}$ in moderate yields (Scheme 28). ${ }^{94}$ These products are formed through the C-protonation of the ylide, followed by displacement of $\mathrm{PhI}$ with fluoride ion.<smiles>[R]C(=O)C([I-][PH+])=C([R])C(=O)[IH]</smiles>

59

$$
\mathrm{R}^{1}=\mathrm{Ph} \text { or } 4-\mathrm{NO}_{2} \mathrm{C}_{6} \mathrm{H}_{4}
$$$$
\mathrm{R}^{2}=\mathrm{CH}_{3} \text { or } \mathrm{OEt}
$$

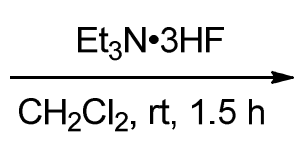

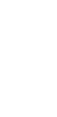<smiles>[R]C(=O)C(F)C([R])=O</smiles>

Scheme 28. Reactions of iodonium ylides with $\mathrm{Et}_{3} \mathrm{~N} \cdot 3 \mathrm{HF}$.

In sharp contrast to the reactions of aryliodonium ylides with acids, Satyamurthy and Barrio have found that the reactions of ylides with nucleophiles $\left(\mathrm{F}^{-}, \mathrm{Cl}^{-}, \mathrm{Br}^{-}\right.$, etc.) in polar aprotic solvents such as acetonitrile, tetrahydrofuran, dimethylsulfoxide, dimethylacetamide and dimethylformamide lead to regioselective substitution of the nucleophile on the aromatic ring instead of the dione ring. ${ }^{75}$ For example, heating phenyliodonium ylides $\mathbf{5 8}$ with dried KF- 
Kryptofix $\left(\mathrm{K}_{222}\right)$ complex in dry DMF affords fluoroarenes $\mathbf{6 1}$ as main products and hydrocarbons 62 as byproducts due to a radical channel competing with the nucleophilic substitution reaction (Scheme 29). No product of fluorination of the $\beta$-dicarbonyl moiety was detected in this reaction. ${ }^{75}$
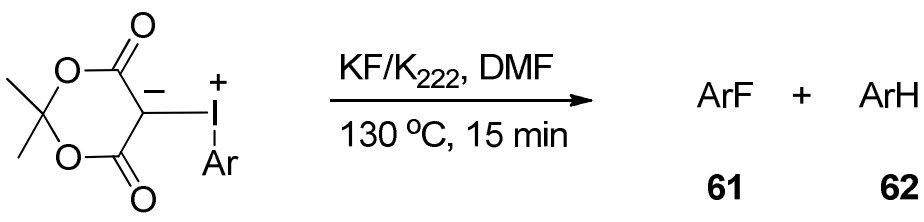

58

$$
\begin{aligned}
\mathrm{Ar}= & \mathrm{Ph}, 4-\mathrm{MeC}_{6} \mathrm{H}_{4}, 2,4,6-\mathrm{Me}_{3} \mathrm{C}_{6} \mathrm{H}_{2}, 2-\mathrm{MeOC}_{6} \mathrm{H}_{4}, \\
& \text { 3-MeOC } \mathrm{MeO}_{4}, 4-\mathrm{MeOC}_{6} \mathrm{H}_{4}, 4-\mathrm{BrC}_{6} \mathrm{H}_{4}
\end{aligned}
$$

Scheme 29. Reaction of iodonium ylides with fluoride anion in DMF.<smiles>CCOC(=O)OCCNC(Cc1ccc(O)c(O)c1)C(N)Cc1ccc(OC(=O)OCC)c(OC(=O)OCc2ccccc2)c1</smiles>

L-DOPA

$\mathrm{I}_{2} / \mathrm{Phl}\left(\mathrm{OCOCF}_{3}\right)_{2}$

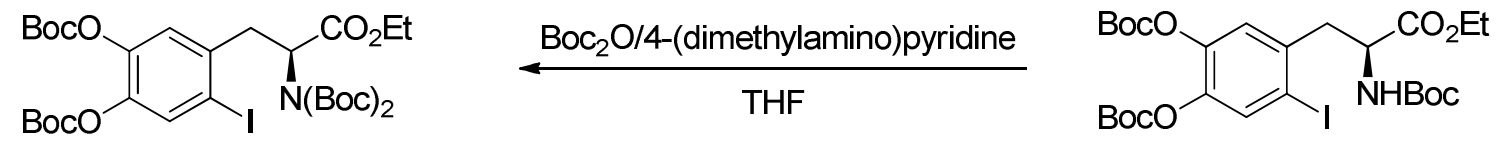<smiles>CC1(CC(=O)O)OO1</smiles><smiles>CCOC(=O)C(Cc1cc(OC(C)(C)C)c(OC(C)(C)C)cc1OC(C)=O)C(=O)OCc1ccccc1</smiles><smiles></smiles>

$\mathrm{Boc}=t-\mathrm{BuOCO}$

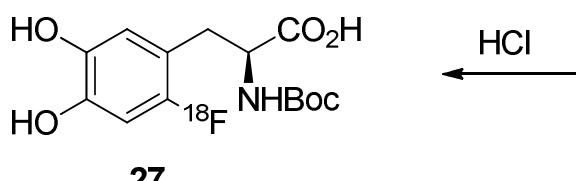<smiles>CCOC(=O)C(Cc1cc(OC(=O)OCc2ccccc2)c(OC(C)(C)C)cc1[I-][I-]1C(=O)OC(C)(C)OC1=O)C(=O)OCc1ccccc1</smiles>

Scheme 30. Radiosynthesis of L-6-[ $\left[{ }^{18}\right.$ F]fluoroDOPA 27. 
This approach has been employed for the radiofluorination of protected L-DOPA derivatives. ${ }^{75}$ A radiochemically pure amino acid L-6- $\left[{ }^{18} \mathrm{~F}\right]$ fluoroDOPA 27 has been produced in amounts usable for human PET studies, as shown in Scheme 30.

The fluorine-18 labeled L-DOPA is a very useful PET imaging agent for mapping dopamine related brain disorders and is the PET biomarker of choice for the diagnosis of Parkinson's disease.

\section{Conclusions}

This review demonstrates that aryliodonium derivatives are becoming increasingly popular reagents in PET for the efficient introduction of $\left[{ }^{18} \mathrm{~F}\right]$-fluoride due to their exceptionally high reactivity in aromatic nucleophilic substitution reactions. Reactions of diaryliodonium salts with cyclotron-produced no-carrier-added $\left[{ }^{18} \mathrm{~F}\right]$-fluoride provide a fast and convenient method of $\left[{ }^{18} \mathrm{~F}\right]$-fluorination. Recent synthetic and mechanistic studies have led to the development of highly regioselective methods of nucleophilic fluorination of aromatic radioligands. We anticipate that this practically important area of hypervalent iodine chemistry will continue to attract significant research activity in the future.

\section{Acknowledgements}

M.S.Y. and V.V.Z. are thankful to the Government of Russia for support of their cooperative research program (FCP, GK11.519.11.5010, Zayavka 2011-1.9-519-024-070, Russian Foundation for Basic Research No. 12-03-00978-a). Our work was also supported by a research grant from the National Science Foundation (CHE-1262479).

\section{References}

1. Wirth, T.; Ed. Hypervalent Iodine Chemistry: Modern Developments in Organic Synthesis. In Top. Curr. Chem. 2003; 224, 2003.

2. Zhdankin, V. V.; Stang, P. J. Chem. Rev. 2008, 108, 5299. http://dx.doi.org/10.1021/cr800332c PMid:18986207 PMCid:2736367

3. Zhdankin, V. V. Arkivoc 2009, (i), 1. http://dx.doi.org/10.3998/ark.5550190.0010.101

4. Zhdankin, V. V. J. Org. Chem. 2011, 76, 1185. http://dx.doi.org/10.1021/jo1024738 PMid:21247180 
5. Yusubov, M. S.; Nemykin, V. N.; Zhdankin, V. V. Tetrahedron 2010, 66, 5745. http://dx.doi.org/10.1016/j.tet.2010.04.046

6. Yusubov, M. S.; Zhdankin, V. V. Curr. Org. Synth. 2012, 9, 247. http://dx.doi.org/10.2174/157017912799829021

7. Silva, J. L. F.; Olofsson, B. Natural Product Reports 2011, 28, 1722.

http://dx.doi.org/10.1039/c1np00028d

PMid:21829843

8. Duschek, A.; Kirsch, S. F. Angew. Chem., Int. Ed. 2011, 50, 1524.

http://dx.doi.org/10.1002/anie.201000873

PMid:21271626

9. Turner, C. D.; Ciufolini, M. A. Arkivoc 2011, (i), 410. http://dx.doi.org/10.3998/ark.5550190.0012.108

10. Quideau, S.; Wirth, T. Tetrahedron 2010, 66, 5737. http://dx.doi.org/10.1016/j.tet.2010.06.026

11. Merritt, E. A.; Olofsson, B. Angew. Chem., Int. Ed. 2009, 48, 9052. http://dx.doi.org/10.1002/anie.200904689 PMid:19876992

12. Yusubov, M. S.; Maskaev, A. V.; Zhdankin, V. V. Arkivoc 2011, (i), 370. http://dx.doi.org/10.3998/ark.5550190.0012.107

13. Kim, D. W.; Jeong, H.-J.; Lim, S. T.; Sohn, M.-H. Nuclear Medicine and Molecular Imaging 2010, 44, 25. http://dx.doi.org/10.1007/s13139-009-0008-1

14. Ametamey, S. M.; Honer, M.; Schubiger, P. A. Chem. Rev. 2008, 108, 1501. http://dx.doi.org/10.1021/cr0782426 PMid:18426240

15. Cai, L.; Lu, S.; Pike, V. W. Eur. J. Org. Chem. 2008, 2853. http://dx.doi.org/10.1002/ejoc.200800114

16. Hollingworth, C.; Gouverneur, V. Chem. Commun. 2012, 48, 2929. http://dx.doi.org/10.1039/c2cc16158c PMid:22334339

17. Lee, S.; Xie, J.; Chen, X. Chem. Rev. 2010, 110, 3087. http://dx.doi.org/10.1021/cr900361p PMid:20225899 PMCid:2868934

18. Miller, P. W.; Long, N. J.; Vilar, R.; Gee, A. D. Angew. Chem., Int. Ed. 2008, 47, 8998. http://dx.doi.org/10.1002/anie.200800222 PMid:18988199

19. Fowler, J. S.; Wolf, A. P. Acc. Chem. Res. 1997, 30, 181. http://dx.doi.org/10.1021/ar960068c 
20. Paans, A. M. J.; van Waarde, A.; Elsinga, P. H.; Willemsen, A. T. M.; Vaalburg, W. Methods 2002, 27, 195. http://dx.doi.org/10.1016/S1046-2023(02)00075-0

21. Phelps, M. E. Proc. Natl. Acad. Sci. U. S. A. 2000, 97, 9226.

http://dx.doi.org/10.1073/pnas.97.16.9226

PMid:10922074 PMCid:16850

22. Wong Dean, F.; Grunder, G.; Brasic James, R. Int. Rev. Psychiatry 2007, 19, 541. http://dx.doi.org/10.1080/09540260701564849

PMid:17896234

23. Lee, C.-M.; Farde, L. Trends in Pharmacological Sciences 2006, 27, 310.

http://dx.doi.org/10.1016/j.tips.2006.04.004

PMid:16678917

24. Burns, H. D.; Hamill, T. G.; Eng, W.-S.; Francis, B.; Fioravanti, C.; Gibson, R. E. Current Opinion in Chemical Biology 1999, 3, 388.

http://dx.doi.org/10.1016/S1367-5931(99)80059-3

25. Miller, J. M.; Kumar, D.; Mann, J. J.; Parsey, R. V. Current Radiopharmaceuticals 2008, 1, 12.

http://dx.doi.org/10.2174/1874471010801010012

26. Halldin, C.; Gulyas, B.; Langer, O.; Farde, L. Q. J. Nucl. Med. 2001, 45, 139.

27. Hamacher, K.; Coenen, H. H.; Stoecklin, G. J. Nucl. Med. 1986, 27, 235.

28. Beuthien-Baumann, B.; Hamacher, K.; Oberdorfer, F.; Steinbach, J. Carbohydr. Res. 2000, $327,107$.

http://dx.doi.org/10.1016/S0008-6215(00)00030-6

29. Dolle, F.; Roeda, D.; Kuhnast, B.; Lasne, M.-C. Fluorine and Health 2008, 3.

30. Lemaire, C.; Gillet, S.; Guillouet, S.; Plenevaux, A.; Aerts, J.; Luxen, A. Eur. J. Org. Chem. 2004, 2899.

http://dx.doi.org/10.1002/ejoc.200400059

31. Carroll, M. A.; Nairne, J.; Woodcraft, J. L. J. Labelled Compd. Radiopharm. 2007, 50, 452. http://dx.doi.org/10.1002/jlcr.1190

32. Sun, H.; DiMagno, S. G. Chem. Commun. 2007, 528.

http://dx.doi.org/10.1039/b614368g

PMid:17252117

33. Sun, H.; DiMagno, S. G. J. Fluorine Chem. 2007, 128, 806.

http://dx.doi.org/10.1016/j.jfluchem.2007.03.009

34. Pike, V. W. Trends in Pharmacological Sciences 2009, 30, 431.

http://dx.doi.org/10.1016/j.tips.2009.05.005

PMid:19616318 PMCid:2805092

35. Pike, V. W.; Aigbirhio, F. I. J. Chem. Soc., Chem. Commun. 1995, 2215. 
36. Ermert, J.; Hocke, C.; Ludwig, T.; Gail, R.; Coenen, H. H. J. Labelled Compd. Radiopharm. 2004, 47, 429. http://dx.doi.org/10.1002/jlcr.830

37. Okuyama, T.; Takino, T.; Sueda, T.; Ochiai, M. J. Am. Chem. Soc. 1995, 117, 3360. http://dx.doi.org/10.1021/ja00117a006

38. Hartmann, C.; Meyer, V. Ber. Dtsch. Chem. Ges. 1894, 27, 426. http://dx.doi.org/10.1002/cber.18940270183

39. Grushin, V. V. Chem. Soc. Rev. 2000, 29, 315. http://dx.doi.org/10.1039/a909041j

40. Yusubov, M. S.; Yusubova, R. Y.; Nemykin, V. N.; Zhdankin, V. V. J. Org. Chem. 2013, 78, 3767.

http://dx.doi.org/10.1021/jo400212u

PMid:23480389

41. Chun, J.-H.; Lu, S.; Lee, Y.-S.; Pike, V. W. J. Org. Chem. 2010, 75, 3332.

http://dx.doi.org/10.1021/jo100361d

PMid:20361793 PMCid:2891105

42. Chun, J.-H.; Lu, S.; Pike, V. W. Eur. J. Org. Chem. 2011, 4439.

http://dx.doi.org/10.1002/ejoc.201100382

PMid:22016665 PMCid:3195448

43. Carroll, M. A.; Pike, V. W.; Widdowson, D. A. Tetrahedron Lett. 2000, 41, 5393. http://dx.doi.org/10.1016/S0040-4039(00)00861-3

44. Chun, J.-H.; Pike, V. W. J. Org. Chem. 2012, 77, 1931.

http://dx.doi.org/10.1021/jo202517v

PMid:22276914 PMCid:3288786

45. Telu, S.; Chun, J.-H.; Simeon, F. G.; Lu, S.; Pike, V. W. Org. Biomol. Chem. 2011, 9, 6629. http://dx.doi.org/10.1039/c1ob05555k

PMid:21845279 PMCid:3186059

46. Lee, B. C.; Kim, J. S.; Kim, B. S.; Son, J. Y.; Hong, S. K.; Park, H. S.; Moon, B. S.; Jung, J. H.; Jeong, J. M.; Kim, S. E. Bioorganic \& Medicinal Chemistry 2011, 19, 2980.

http://dx.doi.org/10.1016/j.bmc.2011.03.029

PMid:21478020

47. Moon, B. S.; Kil, H. S.; Park, J. H.; Kim, J. S.; Park, J.; Chi, D. Y.; Lee, B. C.; Kim, S. E. Org. Biomol. Chem. 2011, 9, 8346.

http://dx.doi.org/10.1039/c1ob06277h

PMid:22057475

48. Basuli, F.; Wu, H.; Griffiths, G. L. J. Labelled Compd. Radiopharm. 2011, 54, 224.

http://dx.doi.org/10.1002/jlcr.1853

PMid:21532942 PMCid:3083861

49. Ochiai, M.; Kitagawa, Y.; Toyonari, M. Arkivoc 2003, (vi), 43.

http://dx.doi.org/10.3998/ark.5550190.0004.606 
50. Ochiai, M.; Takaoka, Y.; Masaki, Y.; Nagao, Y.; Shiro, M. J. Am. Chem. Soc. 1990, 112, 5677. http://dx.doi.org/10.1021/ja00170a063

51. Ochiai, M.; Kitagawa, Y.; Takayama, N.; Takaoka, Y.; Shiro, M. J. Am. Chem. Soc. 1999, $121,9233$. http://dx.doi.org/10.1021/ja992236c

52. Lancer, K. M.; Wiegand, G. H. J. Org. Chem. 1976, 41, 3360. http://dx.doi.org/10.1021/jo00883a004

53. Yamada, Y.; Okawara, M. Bull. Chem. Soc. Jap. 1972, 45, 1860. http://dx.doi.org/10.1246/bcsj.45.1860

54. Wang, B.; Cerny, R. L.; Uppaluri, S.; Kempinger, J. J.; Di Magno, S. G. J. Fluorine Chem. 2010, 131, 1113. http://dx.doi.org/10.1016/j.jfluchem.2010.04.004 PMid:21057607 PMCid:2967785

55. Wang, B.; Qin, L.; Neumann, K. D.; Uppaluri, S.; Cerny, R. L.; Di Magno, S. G. Org. Lett. 2010, 12, 3352. http://dx.doi.org/10.1021/ol101154h PMid:20617820 PMCid:2925243

56. Lee, Y.-S.; Hodoscek, M.; Chun, J.-H.; Pike, V. W. Chem.--Eur. J. 2010, 16, 10418. http://dx.doi.org/10.1002/chem.201000607 PMid:20632418 PMCid:2962621

57. Van der Puy, M. J. Fluorine Chem. 1982, 21, 385. http://dx.doi.org/10.1016/S0022-1139(00)81524-9

58. Shah, A.; Pike, V. W.; Widdowson, D. A. J. Chem. Soc., Perkin Trans. 1 1998, 2043.

59. Carroll, M. A.; Nairne, J.; Smith, G.; Widdowson, D. A. J. Fluorine Chem. 2007, 128, 127. http://dx.doi.org/10.1016/j.jfluchem.2006.10.018

60. Carroll, M. A.; Jones, C.; Tang, S.-L. J. Labelled Compd. Radiopharm. 2007, 50, 450. http://dx.doi.org/10.1002/jlcr.1189

61. Wadsworth, H. J.; Widdowson, D. A.; Wilson, E.; Carroll, M. A. Patent WO 2005061415 A1, 2005.

62. Wang, B.; Graskemper, J. W.; Qin, L.; DiMagno, S. G. Angew. Chem., Int. Ed. 2010, 49, 4079.

http://dx.doi.org/10.1002/anie.201000695

PMid:20425876 PMCid:3498817

63. Graskemper, J. W.; Wang, B.; Qin, L.; Neumann, K. D.; DiMagno, S. G. Org. Lett. 2011, 13, 3158.

http://dx.doi.org/10.1021/ol201080c

PMid:21591627 PMCid:3126865 
64. Martin-Santamaria, S.; Carroll, M. A.; Carroll, C. M.; Carter, C. D.; Rzepa, H. S.;

Widdowson, D. A.; Pike, V. W. Chem. Commun. 2000, 649.

http://dx.doi.org/10.1039/b000868k

65. Ross, T. L.; Ermert, J.; Hocke, C.; Coenen, H. H. J. Am. Chem. Soc. 2007, 129, 8018. http://dx.doi.org/10.1021/ja066850h

PMid:17536798

66. Onys'ko, P. P.; Kim, T. V.; Kiseleva, O. I.; Rassukana, Y. V.; Gakh, A. A. J. Fluorine Chem. 2009, 130, 501.

http://dx.doi.org/10.1016/j.jfluchem.2009.02.001

67. Wuest, F. R.; Kniess, T. J. Labelled Compd. Radiopharm. 2003, 46, 699.

http://dx.doi.org/10.1002/jlcr.709

68. Wuest, F. R.; Hoehne, A.; Metz, P. Org. Biomol. Chem. 2005, 3, 503.

http://dx.doi.org/10.1039/b412871k

PMid:15678189

69. Wuest, F. R.; Kniess, T. J. Labelled Compd. Radiopharm. 2004, 47, 457.

http://dx.doi.org/10.1002/jlcr.834

70. Zhang, M.-R.; Kumata, K.; Suzuki, K. Tetrahedron Lett. 2007, 48, 8632.

http://dx.doi.org/10.1016/j.tetlet.2007.10.025

71. Lee, B. C.; Dence, C. S.; Zhou, H.; Parent, E. E.; Welch, M. J.; Katzenellenbogen, J. A.

Nuclear Medicine and Biology 2009, 36, 147.

http://dx.doi.org/10.1016/j.nucmedbio.2008.11.002

PMid:19217526 PMCid:2774759

72. Lee, B. C.; Lee, K. C.; Lee, H.; Mach, R. H.; Katzenellenbogen, J. A. Bioconjugate Chem. 2007, 18, 514.

http://dx.doi.org/10.1021/bc060191g

PMid:17315977

73. Chun, J.-H.; Pike, V. W. Eur. J. Org. Chem. 2012, 4541.

74. Basuli, F.; Wu, H.; Li, C.; Shi, Z.-D.; Sulima, A.; Griffiths, G. L. J. Labelled Compd. Radiopharm. 2011, 54, 633.

http://dx.doi.org/10.1002/jlcr.1898

75. Satyamurthy, N.; Barrio, J. R. WO 2010117435, 2010.

76. Gudriniece, E.; Neiland, O.; Vanags, G. Zh. Obshch. Khim. 1957, 27, 2737.

77. Kirmse, W. Eur. J. Org. Chem. 2005, 237.

http://dx.doi.org/10.1002/ejoc.200400415

78. Muller, P.; Allenbach, Y. F.; Chappellet, S.; Ghanem, A. Synthesis 2006, 1689. http://dx.doi.org/10.1055/s-2006-926452

79. Muller, P. Acc. Chem. Res. 2004, 37, 243.

http://dx.doi.org/10.1021/ar0202619

PMid:15096061

80. Malamidou-Xenikaki, E.; Spyroudis, S. Synlett 2008, 2725. 
81. Hadjiarapoglou, L.; Spyroudis, S.; Varvoglis, A. J. Am. Chem. Soc. 1985, 107, 7178. http://dx.doi.org/10.1021/ja00310a072

82. Hatjiarapoglou, L.; Varvoglis, A.; Alcock, N. W.; Pike, G. A. J. Chem. Soc., Perkin Trans. 1 1988, 2839.

83. Goudreau, S. R.; Marcoux, D.; Charette, A. B. J. Org. Chem. 2009, 74, 470.

http://dx.doi.org/10.1021/jo802208q

PMid:19032040

84. Cardinale, J.; Ermert, J. Tetrahedron Lett. 2013, 54, 2067.

http://dx.doi.org/10.1016/j.tetlet.2013.02.018

85. Zhu, S.-Z. Heteroatom Chem. 1994, 5, 9. http://dx.doi.org/10.1002/hc.520050104

86. Hackenberg, J.; Hanack, M. J. Chem. Soc., Chem. Commun. 1991, 470.

87. Zhu, S.; Chen, Q. J. Chem. Soc., Chem. Commun. 1990, 1459.

88. Zhu, S.; Chen, Q.; Kuang, W. J. Fluorine Chem. 1993, 60, 39. http://dx.doi.org/10.1016/S0022-1139(00)82192-2

89. Goudreau, S. R.; Marcoux, D.; Charette, A. B.; Hughes, D. Org. Synth. 2010, 87, 115.

90. Zhu, C.; Yoshimura, A.; Ji, L.; Wei, Y.; Nemykin, V. N.; Zhdankin, V. V. Org. Lett. 2012, 14,3170 .

http://dx.doi.org/10.1021/ol301268j

PMid:22625654

91. Zhu, C.; Yoshimura, A.; Solntsev, P.; Ji, L.; Wei, Y.; Nemykin, V. N.; Zhdankin, V. V. Chem. Commun. 2012, 48, 10108.

http://dx.doi.org/10.1039/c2cc35708a

PMid:22955183

92. Pongratz, E.; Kappe, T. Monatsh. Chem. 1984, 115, 231. http://dx.doi.org/10.1007/BF00798414

93. Neilands, O. Zh. Org. Khim. 1965, 1, 1858.

94. Gondo, K.; Kitamura, T. Molecules 2012, 17, 6625. http://dx.doi.org/10.3390/molecules17066625

PMid:22728358 


\section{Authors' Biographies}

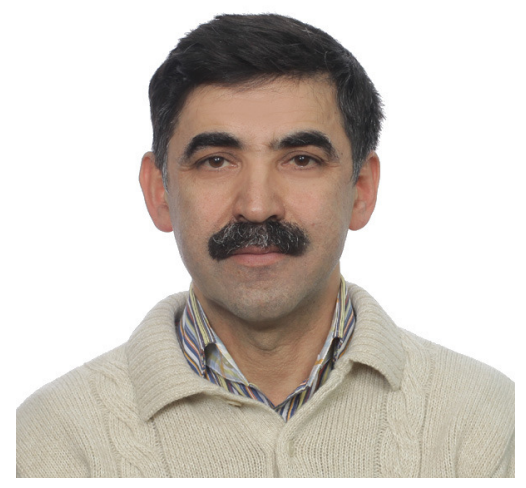

Mekhman S. Yusubov was born in the Rebublic of Georgia. His M.S. (1985), Ph.D. (1991), and Doctor of Chemical Sciences (1998) degrees were earned at Tomsk Polytechnic University in the laboratory of Professor Victor D. Filimonov. He is Head of the Chemistry Department at the Siberian State Medical University and a Professor of Tomsk Polytechnic University. Since 1994 he has been involved in extensive international collaborative research programs with leading research laboratories in South Korea, Germany and the United Kingdom. In 2004 he started a joint research project in the area of hypervalent iodine chemistry with Professor V. V. Zhdankin at the University of Minnesota Duluth. His main research interests are in the fields of chemistry of natural products and hypervalent iodine reagents. Professor M. S. Yusubov has published over 100 scientific papers.

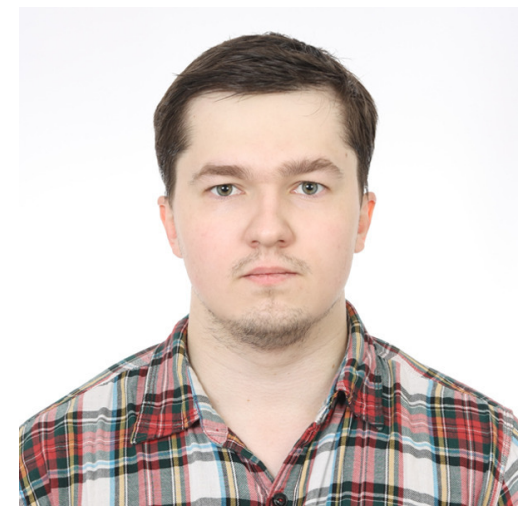

Dmitry Y. Svitich was born in Tomsk, Russian Federation. In 2012 he graduated from Tomsk Polytechnic National Research University with an M.S. degree in Organic Chemistry. He obtained Ph.D. in Organic Chemistry in the Department of Biotechnological and Organic Chemistry at the same university. In 2012 he joined the research group of Professor Mekhman Yusubov at the Siberian State Medical University in Tomsk. His current research is focused on the development of new hypervalent iodine reagents for organic and medicinal chemistry. 


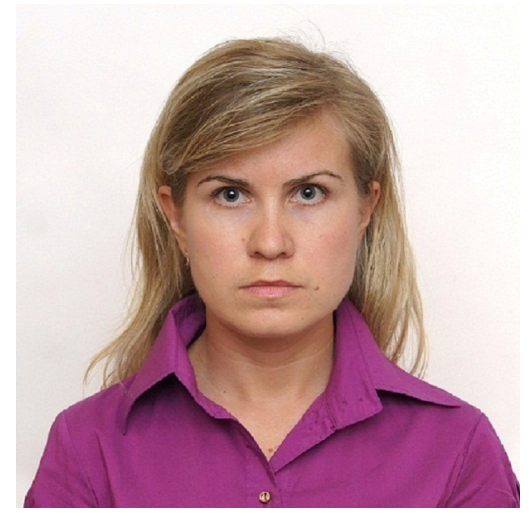

Mariia S. Larkina was born in Berzovsky, Kemerovo region, Russian Federation. In 2006 she graduated from the Department of Pharmacy of the Siberian State Medical University (Tomsk, Russia) with a Pharmacy Degree. She obtained Ph.D. in Pharmaceutical Sciences in 2011 at the Department of Pharmacy of the Siberian State Medical University. In 2011 she joined the research group of Professor Mekhman Yusubov at the same university in Tomsk. Her current research is focused on the development of new hypervalent iodine reagents for organic and medicinal chemistry.

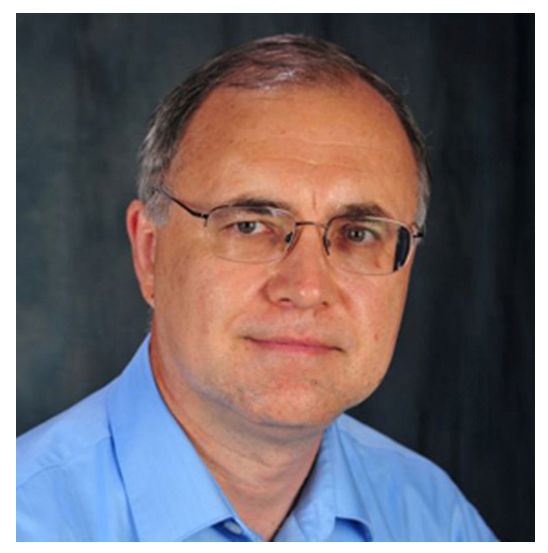

Viktor V. Zhdankin was born in Ekaterinburg, Russian Federation. His M.S. (1978), Ph.D. (1981), and Doctor of Chemical Sciences (1986) degrees were earned at Moscow State University in the research laboratories of Professor Nikolay S. Zefirov. He moved to the University of Utah in 1990, where he worked for three years as Instructor of Organic Chemistry and Research Associate with Professor Peter J. Stang. In 1993, he joined the faculty of the University of Minnesota Duluth, where he is currently Professor of Chemistry. He has published over 220 scientific papers, edited several books, and co-authored the Handbook of Heterocyclic Chemistry ( $3^{\text {rd }}$ Edition, 2010) with Professors A. R. Katritzky, C. A. Ramsden, and J. A. Joule. His main research interests are in the fields of synthetic and mechanistic organic chemistry of hypervalent main-group elements (iodine, xenon, selenium, sulfur, and phosphorus) and organofluorine chemistry. In 2011 he was a recipient of a National Award of the American 
Chemical Society for Creative Research \& Applications of Iodine Chemistry. Since 2003 he has been Scientific Editor and a Member of the Control Board of Arkivoc. 